\title{
Phytosterols and Novel Triterpenes Recovered from Industrial Fermentation Coproducts Exert In Vitro Anti-Inflammatory Activity in Macrophages
}

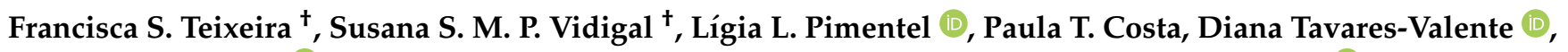 \\ João Azevedo-Silva $\mathbb{C}^{(}$, Manuela E. Pintado, João C. Fernandes and Luís M. Rodríguez-Alcalá *(D)
}

check for updates

Citation: Teixeira, F.S.; Vidigal, S.S.M.P.; Pimentel, L.L.; Costa, P.T.; Tavares-Valente, D.; Azevedo-Silva, J.; Pintado, M.E.; Fernandes, J.C.; Rodríguez-Alcalá, L.M. Phytosterols and Novel Triterpenes Recovered from Industrial Fermentation Coproducts Exert In Vitro Anti-Inflammatory Activity in Macrophages. Pharmaceuticals 2021, 14, 583. https://doi.org/10.3390/ ph14060583

Academic Editor: Pawel Kafarski

Received: 20 April 2021

Accepted: 14 June 2021

Published: 18 June 2021

Publisher's Note: MDPI stays neutral with regard to jurisdictional claims in published maps and institutional affiliations.

Copyright: (c) 2021 by the authors. Licensee MDPI, Basel, Switzerland. This article is an open access article distributed under the terms and conditions of the Creative Commons Attribution (CC BY) license (https:/ / creativecommons.org/licenses/by/ $4.0 /)$.
CBQF-Centro de Biotecnologia e Química Fina-Laboratório Associado, Universidade Católica Portuguesa, Escola Superior de Biotecnologia, Rua Diogo Botelho 1327, 4169-005 Porto, Portugal; fsteixeira@porto.ucp.pt (F.S.T.); svidigal@porto.ucp.pt (S.S.M.P.V.); lpimentel@porto.ucp.pt (L.L.P.); ptcosta@porto.ucp.pt (P.T.C.); dvalente@porto.ucp.pt (D.T.-V.); jasilva@porto.ucp.pt (J.A.-S.); mpintado@porto.ucp.pt (M.E.P.); jcfernandes@porto.ucp.pt (J.C.F.)

* Correspondence: lalcala@porto.ucp.pt

+ Both authors contributed equally.

Abstract: The unstoppable growth of human population that occurs in parallel with all manufacturing activities leads to a relentless increase in the demand for resources, cultivation land, and energy. In response, currently, there is significant interest in developing strategies to optimize any available resources and their biowaste. While solutions initially focused on recovering biomolecules with applications in food, energy, or materials, the feasibility of synthetic biology in this field has been demonstrated in recent years. For instance, it is possible to genetically modify Saccharomyces cerevisiae to produce terpenes for commercial applications (i.e., against malaria or as biodiesel). But the production process, similar to any industrial activity, generates biowastes containing promising biomolecules (from fermentation) that if recovered may have applications in different areas. To test this hypothesis, in the present study, the lipid composition of by-products from the industrial production of $\beta$-farnesene by genetically modified Saccharomyces cerevisiae are studied to identify potentially bioactive compounds, their recovery, and finally, their stability and in vitro bioactivity. The assayed biowaste showed the presence of triterpenes, phytosterols, and 1-octacosanol which were recovered through molecular distillation into a single fraction. During the assayed stability test, compositional modifications were observed, mainly for the phytosterols and 1-octacosanol, probably due to oxidative reactions. However, such changes did not affect the in vitro bioactivity in macrophages, where it was found that the obtained fraction decreased the production of TNF- $\alpha$ and IL-6 in lipopolysaccharide (LPS)-induced inflammation.

Keywords: biowaste; triterpenes; 1-octacosanol; phytosterols; stability test; molecular distillation; macrophages; inflammation; IL-6

\section{Introduction}

The technological advances that humankind has achieved since the first industrial revolution (i.e., 1760) to nowadays, have led to population growth, resource utilization, and environmental alterations more rapidly than recorded in previous ages. Thus, according to recent calculations, it is expected that, by 2030, the human population of the Earth could be 8.5 billion, and 9.7 billion by 2050 [1], increasing the demand for both energy and natural resources [2]. Indeed, there is significant concern regarding the future availability of fertile cropland, pure water, and energy [3,4], aggravated by climate change that disrupts society, the environment, and economics [5] in a scenario where humankind may reach a critical point in its development [6].

The need to bring sustainability policies to social, economic, and environmental features has resulted in the apparition of circular, green, and bioeconomy concepts [7]. 
Specifically, bioeconomy focuses on the reutilization of biological wastes from land and sea to produce food, energy, and various materials [2]. For example, processing of fruits, vegetables, dairy, bakery, and meat products, generates around 1.3 billion tons of scrap materials. In fact, by 2025, the urban quantum of wastes is estimated to be 416 million tons, whereas, in 2005, it was 278 million tons [8].

In addition to improving our efficiency of food production and distribution, recovery and reutilization are emerging as potential solutions. Several biomolecules (i.e., antioxidants, pectin, fiber, phenolics, and lipids) can still be found in such wastes, and therefore applied in animal feed [9], biomaterials [10], and sunscreen filters [11].

A paradigm in green economy is the utilization of biofuels to replace fossil oils. Thus, for bioethanol as octane additive [12], the so-called first-generation is produced during the fermentation of sugar from sugarcane or other starch-containing raw materials such as molasses $[13,14]$. However, this activity has recently been merged with the principles of bioeconomy, since, in second-generation bioethanol, hemicellulose and cellulose from lignocellulosic biomass, biowastes of sugarcane such as bagasse and straw, are hydrolysed to sugars and also fermented into ethanol [15]. Finally, third-generation biofuels focus on marine algae due to its high carbohydrate content [16].

This development has been motivated by the fact that production from biomass feedstock is preferable, since there is no need for extra land or competition with food production such as is expected to happen with sugarcane if the demand of this crop continues to increase according to predictions [17]. Moreover, for biodiesel elaboration, since it is composed of long chain fatty acid esters from vegetable oils and animal fats, the utilization of non-edible plant oils [18] or tallow waste [19] has also been assayed with promising results.

In a more straightforward approach to obtain valuable molecules, a solution has been proposed elsewhere based on synthetic biology where microorganisms are transformed with the appropriate set of genes [20,21]. Specifically, by genetic engineering, it has already been possible to produce terpenes and terpenoids in Saccharomyces cerevisiae with applications in pharmaceuticals and biofuels [22]. Artemisinin (i.e., an antimalarial drug) [23] and $\beta$-farnesene (i.e., biodiesel) [24] are examples of industrial-scale molecules produced by genetically modified Saccharomyces cerevisiae.

This is certainly an emerging field where the principles of bioeconomy can be applied to synthetic-biology-based processes. In fact, in the lipidome of wild type Saccharomyces cerevisiae, the presence of up to 160 different molecular species has been reported, where ergosterol is one of the most relevant compounds [25]. Furthermore, this sterol was able to ameliorate inflammation in diabetic nephropathy mice [26] as well as in microglia cells [27]. Moreover, it must be noted that, as previously mentioned, in general, the fermentative processes use sugar/molasses as carbon and energy sources. The producing plant (i.e., sugarcane) has been described as containing phytochemicals [28,29], also associated with anti-inflammatory properties in macrophages and mice [30]. Thus, it can be hypothesized that some of those potentially bioactive molecules could be found and recovered in the fermentation biowastes.

In the current COVID-19 pandemic scenario, the search for any available sources of bioactive lipids and mainly those with anti-inflammatory properties would be of special interest [31].

Accordingly, in this study, we aim at screening for the presence of potentially bioactive lipids in biowastes from the fermentative production of $\beta$-farnesene, and then to devise a strategy for their isolation and further characterization of both in vitro bioactivity and stability. The obtained information should allow us to unravel the suitability of industrial fermentation by-products as potential sources of lipids to be used as bioactive ingredients. 


\section{Results and Discussion}

2.1. Composition and Presence of Potentially Bioactive Lipids in $\beta$-Farnesene Distillation Residue (FDR) Samples

During the lipid profiling of $\beta$-farnesene distillation residue (FDR), compounds have been observed by elution in the chromatographic region of glycolipids using the HPLCELSD technique (data not shown) with a concentration of 46.51/100 g lipids (Table 1). Such compounds are common in plant samples [32] and their presence could be related to the utilization of sugarcane syrups during the fermentative processes to produce $\beta$-farnesene, but in lower concentrations than those detected. For the purpose of confirming the presence of glycolipids, an FDR methanol fraction was analyzed by shotgun mass spectrometry in a QTOF instrument (Supplementary Materials Figure S7). The fragmentation pattern detected by the mass spectrometer revealed several ions (i.e., m/z) from 200 to $1400 \mathrm{~m} / \mathrm{z}$, and the distribution of intensities resembled that of a Gaussian distribution. Further LCQTOF analyses showed only one eluting peak, confirming the Gaussian distribution of ions (Figure S8). This agrees with the presence of oligomers, suggesting that this compound can be a polymer [33]. In fact, since FDR is a by-product of the distillation of $\beta$-farnesene (PR 15), this polymer may arise during the process. Nevertheless, elsewhere, assays have successfully demonstrated the utilization of $\beta$-farnesene to produced biopolymers through anionic or cationic pathways [34] and involving redox reactions [35].

Table 1. Lipid class compositions (g/100 g of lipids) of the FDR and feed samples at the different assay times.

\begin{tabular}{|c|c|c|c|c|c|c|c|c|c|c|c|c|}
\hline \multirow{2}{*}{$\frac{\text { FDR }}{\text { Compound }}$} & \multicolumn{3}{|c|}{ T0 } & \multicolumn{3}{|c|}{ T1 } & \multicolumn{3}{|c|}{ T2 } & \multicolumn{3}{|c|}{ T3 } \\
\hline & Mean & & SD & Mean & & SD & Mean & & SD & Mean & & SD \\
\hline Hydrocarbons & В 43.29 & \pm & 0.17 & B 44.23 & \pm & 1.61 & A 52.82 & \pm & 0.51 & A 54.79 & \pm & 0.02 \\
\hline Wax esters & $\mathrm{AB} 0.22$ & \pm & 0.05 & ${ }^{\mathrm{A}} 0.23$ & \pm & 0.01 & В 0.17 & \pm & 0.01 & $\mathrm{C}_{0.14}$ & \pm & 0.02 \\
\hline Triglycerides & A 4.21 & \pm & 0.03 & A 4.32 & \pm & 0.10 & В 3.01 & \pm & 0.25 & B 2.59 & \pm & 0.11 \\
\hline Fatty alcohols & A 2.00 & \pm & 0.10 & A 2.18 & \pm & 0.09 & В 1.49 & \pm & 0.17 & В 1.29 & \pm & 0.19 \\
\hline Phytosterols & A 0.78 & \pm & 0.01 & A 0.74 & \pm & 0.02 & B 0.53 & \pm & 0.03 & $\mathrm{C}_{0.36}$ & \pm & 0.07 \\
\hline Diglycerides & A 2.62 & \pm & 0.12 & A 2.51 & \pm & 0.02 & В 1.67 & \pm & 0.13 & B 1.61 & \pm & 0.02 \\
\hline Free fatty acids & ${ }^{\mathrm{B}} 0.33$ & \pm & 0.03 & A 0.48 & \pm & 0.05 & В 0.31 & \pm & 0.02 & B 0.34 & \pm & 0.03 \\
\hline Monoglycerides & $\mathrm{C}_{0.04}$ & \pm & 0.01 & B 0.10 & \pm & 0.02 & A 0.17 & \pm & 0.01 & A 0.16 & \pm & 0.01 \\
\hline Polymer & A 46.51 & \pm & 0.22 & A 45.20 & \pm & 1.67 & В 39.84 & \pm & 0.52 & В 38.70 & \pm & 0.46 \\
\hline Feed & \multicolumn{3}{|c|}{ T0 } & \multicolumn{3}{|c|}{ T1 } & \multicolumn{3}{|c|}{$\mathrm{T} 2$} & \multicolumn{3}{|c|}{ T3 } \\
\hline Compound & Mean & & SD & Mean & & SD & Mean & & SD & Mean & & SD \\
\hline Hydrocarbons & В 39.54 & \pm & 0.92 & В 39.71 & \pm & 0.91 & A 52.60 & \pm & 0.62 & A 49.46 & \pm & 2.34 \\
\hline Wax esters & A 0.11 & \pm & 0.01 & ${ }^{\mathrm{A}} 0.11$ & \pm & 0.02 & B 0.07 & \pm & 0.01 & $C_{0.06}$ & \pm & 0.01 \\
\hline Triglycerides & A 4.34 & \pm & 0.15 & A 4.56 & \pm & 0.16 & B 2.72 & \pm & 0.06 & $C_{2.05}$ & \pm & 0.15 \\
\hline Fatty alcohols & A 1.75 & \pm & 0.03 & A 1.75 & \pm & 0.05 & В 0.98 & \pm & 0.01 & В 0.98 & \pm & 0.06 \\
\hline Phytosterols & ${ }^{\mathrm{A}} 0.73$ & \pm & 0.02 & A 0.74 & \pm & 0.03 & B 0.44 & \pm & 0.02 & $\mathrm{C}_{0.37}$ & \pm & 0.03 \\
\hline Diglycerides & A 2.08 & \pm & 0.05 & A 1.95 & \pm & 0.20 & B 1.22 & \pm & 0.05 & $\mathrm{C}_{0.90}$ & \pm & 0.22 \\
\hline Free fatty acids & 0.30 & \pm & 0.04 & 0.31 & \pm & 0.07 & 0.20 & \pm & 0.02 & 0.22 & \pm & 0.01 \\
\hline Monoglycerides & $\mathrm{C}_{0.04}$ & \pm & 0.01 & ${ }^{\mathrm{A}} 0.10$ & \pm & 0.01 & ${ }^{\mathrm{B}} 0.06$ & \pm & 0.01 & A 0.09 & \pm & 0.01 \\
\hline Polymer & A 51.11 & \pm & 0.79 & A 50.78 & \pm & 0.85 & A 41.69 & \pm & 0.66 & В 45.88 & \pm & 2.37 \\
\hline
\end{tabular}

Results expressed as mean $\pm \mathrm{SD}(n=3)$. T0, time 0 (initial); T1, time 1st month; T2, time 2nd month; T3, time 3rd month end of study. Different superscript letters in a row for significant differences along time $(p<0.05)$.

Moreover, the HPLC-ELSD analyses, in addition to the presence of polymers as mentioned above, showed that hydrocarbons were one of the major lipid compounds in an FDR sample (43.29 g/100 g lipids; Table 1). Further analysis performed by GC-MS (Table 2) confirmed that the principal lipid family consisted of terpenes, and this group was integrated by $\beta$-farnesene (PR 15, $133 \mathrm{~g} / \mathrm{kg}$, as the main compound), farnesol (PR 15:2c2t16 and PR 15:2t2t16), a sesterterpene (PR 25), and triterpenes. Regarding these latter compounds, five different triterpenes were detected in both FDR and feed samples. For their annotation, they were grouped according to their chromatographic elution (i.e., by 
retention time) and labeled from I to VIII (Supplementary Materials Figure S1). Afterwards, the mass spectra of the matching peaks in each sample were compared. It was found that the fragmentation pattern of peaks with the same retention time was similar, therefore, suggesting that they were the same compound. In all cases, the base peak was $69 \mathrm{~m} / \mathrm{z}$, while the other secondary ions were $41,55,81,95,105,120,133,145$, and $160 \mathrm{~m} / \mathrm{z}$ Figures S2-S5. The highest $\mathrm{m} / \mathrm{z}$ detected was $408 \mathrm{~m} / \mathrm{z}$, which may point out to be the molecular ion. Thus, compounds I to VIII seem to belong to the same family but the differences in retention time highlight that they have some structural differences.

Table 2. Profile (g/kg) in terpenes, fatty alcohols, and phytosterols in the FDR and Feed samples at the different assay times.

\begin{tabular}{|c|c|c|c|c|c|c|c|c|c|c|c|c|}
\hline \multirow{2}{*}{$\begin{array}{c}\text { FDR } \\
\text { Compound }\end{array}$} & \multicolumn{3}{|c|}{ T0 } & \multicolumn{3}{|c|}{ T1 } & \multicolumn{3}{|c|}{ T2 } & \multicolumn{3}{|c|}{ T3 } \\
\hline & Mean & & SD & Mean & & SD & Mean & & SD & Mean & & SD \\
\hline$\beta$-Farnesene (PR 15) & A 133.48 & \pm & 2.81 & В 124.35 & \pm & 5.56 & C 107.19 & \pm & 1.11 & D 97.15 & \pm & 3.1 \\
\hline Farnesol $(\mathrm{Z}, \mathrm{E})(\mathrm{PR} 15: 2 \mathrm{c} 2 \mathrm{t} 6)$ & A 16.26 & \pm & 0.38 & B 14.95 & \pm & 0.38 & B 15.10 & \pm & 0.92 & $\mathrm{C}_{13.02}$ & \pm & 0.48 \\
\hline Farnesol (E,E) (PR 15:2t2t6) & 1.36 & \pm & 0.04 & 1.15 & \pm & 0.08 & 1.35 & \pm & 0.14 & 1.07 & \pm & 0.11 \\
\hline Sesterterpene (PR 25) & 13.5 & \pm & 0.28 & 12.86 & \pm & 0.60 & 11.68 & \pm & 1.36 & 10.53 & \pm & 0.76 \\
\hline Triterpene I (PR 30) & D 2.18 & \pm & 0.01 & $\mathrm{C}_{2.47}$ & \pm & 0.04 & A 3.05 & \pm & 0.18 & B 2.62 & \pm & 0.30 \\
\hline Triterpene III (PR 30) & В 2.36 & \pm & 0.05 & A 3.01 & \pm & 0.09 & A 3.35 & \pm & 0.16 & A 3.09 & \pm & 0.24 \\
\hline Triterpene IV (PR 30) & $C_{42.22}$ & \pm & 0.48 & A 52.96 & \pm & 2.15 & В 46.86 & \pm & 1.28 & B 44.96 & \pm & 0.95 \\
\hline Triterpene VI (PR 30) & 1.77 & \pm & 0.05 & 2.12 & \pm & 0.02 & 1.30 & \pm & 0.25 & 1.63 & \pm & 0.19 \\
\hline Triterpene VIII (PR 30) & $C_{24.03}$ & \pm & 0.38 & A 30.41 & \pm & 1.11 & B 26.21 & \pm & 0.80 & B 25.86 & \pm & 0.94 \\
\hline$\Sigma$ TERPENES & A 237.16 & \pm & 4.46 & A 244.28 & \pm & 9.00 & B 216.09 & \pm & 5.86 & $\mathrm{C}_{199.93}$ & \pm & 5.06 \\
\hline 1-Octacosanol (FOH 28:0) & 1.45 & \pm & 0.31 & 1.13 & \pm & 0.08 & 1.09 & \pm & 0.11 & 0.92 & \pm & 0.12 \\
\hline$\Sigma \mathrm{FOH}$ & A 1.45 & \pm & 0.31 & B 1.13 & \pm & 0.08 & В 1.09 & \pm & 0.11 & B 0.92 & \pm & 0.12 \\
\hline Ergosterol (ST 28:3;O) & B 3.19 & \pm & 0.14 & A 3.72 & \pm & 0.09 & B 3.07 & \pm & 0.26 & $\mathrm{C}_{1.70}$ & \pm & 0.22 \\
\hline Campesterol (ST 28:1;O) & 0.72 & \pm & 0.05 & 0.86 & \pm & 0.01 & 0.94 & \pm & 0.07 & 0.77 & \pm & 0.09 \\
\hline Stigmasterol (ST 29:2;O) & 0.92 & \pm & 0.04 & 1.03 & \pm & 0.02 & 1.07 & \pm & 0.12 & 0.98 & \pm & 0.11 \\
\hline$\beta$-Sitosterol (ST 29:1;O) & 1.29 & \pm & 0.05 & 1.51 & \pm & 0.05 & 1.60 & \pm & 0.15 & 1.47 & \pm & 0.15 \\
\hline$\Sigma \mathrm{ST}$ & A 6.11 & \pm & 0.28 & A 7.11 & \pm & 0.14 & A 6.68 & \pm & 0.59 & B 4.92 & \pm & 0.57 \\
\hline Feed & \multicolumn{3}{|c|}{ T0 } & \multicolumn{3}{|c|}{ T1 } & \multicolumn{3}{|c|}{ T2 } & \multicolumn{3}{|c|}{ T3 } \\
\hline Compound & Mean & & SD & Mean & & SD & Mean & & SD & Mean & & SD \\
\hline$\beta$-Farnesene (PR 15) & В 116.09 & \pm & 1.52 & A 119.95 & \pm & 2.5 & $\mathrm{C}_{101.27}$ & \pm & 0.7 & D 66.30 & \pm & 1.46 \\
\hline Farnesol $(\mathrm{Z}, \mathrm{E})(\mathrm{PR} 15: 2 \mathrm{c} 2 \mathrm{t} 6)$ & A 15.67 & \pm & 0.17 & A 16.47 & \pm & 0.21 & A 16.74 & \pm & 0.15 & B 14.74 & \pm & 0.63 \\
\hline Farnesol (E,E) (PR 15:2t2t6) & 1.27 & \pm & 0.03 & 1.33 & \pm & 0.02 & 1.49 & \pm & 0.02 & 1.24 & \pm & 0.03 \\
\hline Sesterterpene (PR 25) & 14.83 & $\overline{ \pm}$ & 0.14 & 15.14 & \pm & 0.37 & 13.56 & \pm & 0.03 & 13.04 & \pm & 0.80 \\
\hline Triterpene I (PR 30) & $\mathrm{C}_{2.08}$ & \pm & 0.14 & ${ }^{C} 2.67$ & \pm & 0.12 & A 3.08 & \pm & 0.12 & В 2.98 & \pm & 0.20 \\
\hline Triterpene III (PR 30) & В 2.61 & \pm & 0.12 & A 2.84 & \pm & 0.34 & В 3.27 & \pm & 0.09 & В 3.16 & \pm & 0.11 \\
\hline Triterpene IV (PR 30) & B 45.69 & \pm & 0.46 & A 50.11 & \pm & 0.45 & C 44.94 & \pm & 0.63 & $C_{43.95}$ & \pm & 1.45 \\
\hline Triterpene VI (PR 30) & A 2.02 & \pm & 0.06 & A 2.44 & \pm & 0.08 & C 1.57 & \pm & 0.06 & B 1.82 & \pm & 0.16 \\
\hline Triterpene VIII (PR 30) & В 25.99 & \pm & 0.26 & A 28.64 & \pm & 0.36 & C 25.05 & \pm & 0.33 & C 24.84 & \pm & 0.86 \\
\hline$\Sigma$ TERPENES & A 226.26 & \pm & 0.13 & A 239.59 & \pm & 1.39 & В 210.97 & \pm & 1.75 & $\mathrm{C}_{172.08}$ & \pm & 5.46 \\
\hline 1-Octacosanol (FOH 28:0) & 0.25 & \pm & 0.11 & 0.23 & \pm & 0.01 & 0.24 & \pm & 0.02 & 0.21 & \pm & 0.02 \\
\hline$\Sigma \mathrm{FOH}$ & 0.25 & \pm & 0.11 & 0.23 & \pm & 0.01 & 0.24 & \pm & 0.02 & 0.21 & \pm & 0.02 \\
\hline Ergosterol (ST 28:3;O) & B 3.54 & \pm & 0.12 & A 3.70 & \pm & 0.17 & B 3.00 & \pm & 0.14 & $\mathrm{C}_{1.79}$ & \pm & 0.16 \\
\hline Campesterol (ST 28:1;O) & 0.71 & \pm & 0.01 & 0.78 & \pm & 0.05 & 0.88 & \pm & 0.03 & 0.83 & \pm & 0.06 \\
\hline Stigmasterol (ST 29:2;O) & 0.90 & \pm & 0.03 & 1.13 & \pm & 0.02 & 1.22 & \pm & 0.06 & 1.23 & \pm & 0.14 \\
\hline$\beta$-Sitosterol (ST 29:1;O) & 1.36 & \pm & 0.08 & 1.69 & \pm & 0.1 & 1.79 & \pm & 0.08 & 1.76 & \pm & 0.14 \\
\hline$\Sigma \mathrm{ST}$ & A 6.52 & \pm & 0.24 & A 7.31 & \pm & 0.29 & A 6.89 & \pm & 0.17 & B 5.62 & \pm & 0.49 \\
\hline
\end{tabular}

Results expressed as mean \pm SD $(n=3)$. T0, time 0 (initial); T1, time 1st month; T2, time 2nd month; T3, time 3rd month end of study. FOH,

fatty alcohols and ST, sterols. Different superscript letters in a row for significant differences along time $(p<0.05)$.

In FDR samples, since a polymer that may arise from the polymerization of $\beta$ farnesene (PR 15) was detected, the origin of triterpenes I-VIII may also be the dimerization of this compound. When comparing the above-mentioned spectra with the one obtained after GC-MS analysis of a standard of squalene (Figure S6), the same base ion peak can be observed as well as similar secondary ions. The molecular weight of squalene is $410.71 \mathrm{~g} / \mathrm{mol}$ and the possible molecular ion in compounds I-VIII had a m/z of 408, suggesting that, although compounds I-VIII are triterpenes, their structure is slightly different from that of squalene. 
Interestingly, Fischer et al. [36] published a patent describing procedures and conditions for obtaining farnesene dimers: four dimers with molecular formula $\mathrm{C}_{30} \mathrm{H}_{60}$ and molecular weight of $420.84 \mathrm{~g} / \mathrm{mol}$ and another four dimers with the molecular formula $\mathrm{C}_{30} \mathrm{H}_{48}(408.71 \mathrm{~g} / \mathrm{mol})$, which agrees with the characteristics of the PR 30 detected in an FDR sample.

The presence of PR 30 suggests a promising potential of FDR, since other similar triterpenes such as squalene have exhibited high biocompatibility [37] and several publications have reported that PR 30 can act as a drug carrier [38,39], allowing the transport of bioactive compounds (i.e., through the blood brain barrier [40]).

Furthermore, other bioactive lipids have also been detected by HPLC-ELSD, namely fatty alcohols (2.00 g/100 g lipids) and phytosterols (0.78 g/100 g lipids). The GC-MS analysis revealed that these lipid groups were mainly composed of 1-octacosanol (FOH $28: 0,1.45 \mathrm{~g} / \mathrm{kg}$ ) in the case of fatty alcohols (Table 2) and ergosterol (ST 28:3;O, $3.19 \mathrm{~g} / \mathrm{kg}$ ), campesterol (ST 28:1;O, 0.72 g/kg), stigmasterol (ST 29:2;O, $0.92 \mathrm{~g} / \mathrm{kg}$ ), and $\beta$-sitosterol (ST 29:1;O, $1.29 \mathrm{~g} / \mathrm{kg}$ ) for phytosterols.

Different studies have concluded that FOH 28:0 may exert bioactive properties against obesity and related metabolic disorders. When mice were exposed to a high fat diet and

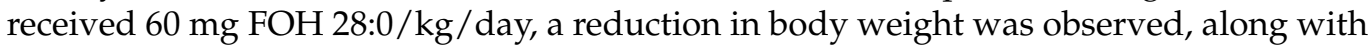
an improvement in insulin resistance and hepatic lipid content [41]. Studies [42] conducted in humans have also found positive effects of $\mathrm{FOH}$ 28:0 supplementation on taekwondo athletes ( $40 \mathrm{mg}$ /day for 6 days) subjected to rapid weight loss through caloric restriction, with high intensity exercise training reporting higher levels of high-density lipoprotein (HDL) with a decrease in low density lipoprotein (LDL) and TG. In addition, in mice exposed to a cage change strategy to induce mild stress and sleep disturbance, doses of 100-200 mg of FOH 28:0/ kg clearly restored stress-affected sleep [43].

Phytosterols are widely recognized to be bioactive compounds that exert positive effects on human health. Thus, EU regulations regarding health claims about plant sterols accept that a human diet supplemented with $0.8 \mathrm{~g}$ phytosterols/day contributes to the maintenance of normal blood cholesterol levels [44].

Therefore, the performed analysis allowed us to identify the presence of compounds with potential bioactivity (FOH 28:0 and phytosterols), while PR 30 may act as a carrier and/or coadjuvant. Accordingly, the following experiments focused on the recovery of fatty alcohols, terpenes, and phytosterols in order to predict physicochemical and bioactivity parameters over an accelerated stability test.

\subsection{Recovery of Bioactive Compounds by Molecular Distillation}

At atmospheric pressure, the boiling points of $\beta$-farnesene, farnesol, and 1-octacosanol are 260,299 , and $428{ }^{\circ} \mathrm{C}$, respectively. Regarding phytosterols, the boiling points of ergosterol and stigmasterol are 250 and $490^{\circ} \mathrm{C}$, respectively. If the detected PR 30 has, as the collected data suggest, a structure similar to squalene, then, its boiling point may be close to that of this molecule (i.e., $458^{\circ} \mathrm{C}$ ). Accordingly, the compounds of interest (i.e., PR 30, 1-octacosanol, and phytosterols) may be recovered together by distillation in a single fraction. This would be a promising approach since distillation could be scaled up to an industrial size.

However, these high temperatures may result in degradation of the molecules, and therefore working at a reduced pressure is required. As described in the Methods and Materials Section, the experiment was performed at $0.5-0.8$ Torr, at a starting temperature of $250{ }^{\circ} \mathrm{C}$, which was gradually increased. Prior to the distillation, FDR was degassed in a vacuum and room temperature for $30 \mathrm{~min}$. This sample was labeled as Feed.

As a first approach, the FDR and Feed samples were compared by FTIR-ATR (Figure 1). Thus, it was possible to detect a band at $3486 \mathrm{~cm}^{-1}$ inherent to the $-\mathrm{OH}$ stretching vibration due to the presence of alcohols, namely farnesol. At $1741 \mathrm{~cm}^{-1}$, there was evidence of the presence of $\mathrm{a}-\mathrm{C}=\mathrm{O}$ stretching vibration band, which might be related to the presence of carboxylic acids, esters, ketones, or aldehydes. At $1297 \mathrm{~cm}^{-1}$, the $-\mathrm{CH}$ deformation 
vibration band was identified and may be related to the presence of unsaturated aliphatic chains, probably from unsaturated farnesene dimers, according to structures described elsewhere [36].

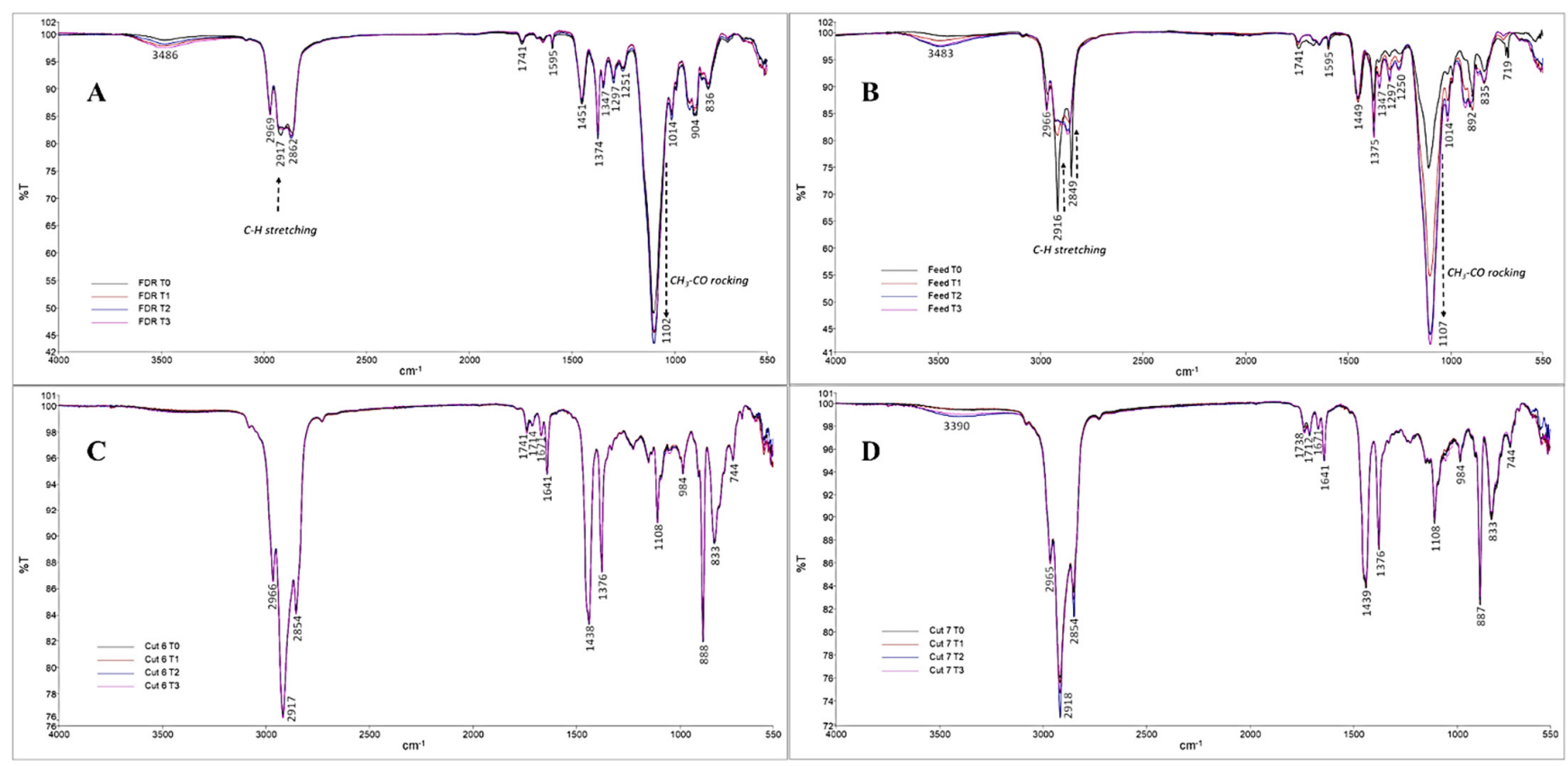

Figure 1. Overlay of the Fourier transform infrared spectroscopy (FTIR) spectra of FDR (A), Feed (B), C6 (C), and C7 (D) samples throughout the stability test (T0, T1, T2, and T3).

According to the gas chromatographic analyses (Table 2), it was observed that the $\beta$-farnesene content in the Feed sample was slightly lower than in that the FDR sample (133.48 g/kg FDR vs. $116.09 \mathrm{~g} / \mathrm{kg}$ Feed, $p>0.05)$. However, the contents of FOH 28:0 were significantly affected after the vacuum degassing step, i.e., $1.45 \mathrm{~g} / \mathrm{kg}$ FDR vs. $0.25 \mathrm{~g} / \mathrm{kg}$ Feed. This difference was also observed in the data obtained by HPLC-ELSD, as fatty alcohols levels in the Feed sample were $1.75 \mathrm{~g} / 100 \mathrm{~g}$ and $2.00 \mathrm{~g} / 100 \mathrm{~g}(p>0.05)$ in the FDR sample.

There were no further alterations observed after the degassing step. Thus, according to the principal component analysis (PCA) (Supplementary Materials Figure S9) of the data obtained by GC-MS and HPLC-ELSD, both the FDR and Feed samples cluster on the positive side of the $x$-axis (PC1), which indicates similarity between these samples.

FOH 28:0 is the main component of policosanol, a mixture of long chain fatty alcohols that can be found in the waxes of sugarcane [45], rice bran [46], wheat and flax straw [47], and other plant materials. Studies conducted on rice bran oil stored for 17 days at $40{ }^{\circ} \mathrm{C}$, have found that only triglycerides were affected by oxidation due to the intramolecular formation of hydroperoxides, mainly in molecular species containing linoleic acid [48]. When FOH 28:0 and phytosterols were isolated from sugarcane rind and heated up to $300{ }^{\circ} \mathrm{C}, 21$ degradation compounds from both FOH 28:0 and phytosterols were found, which were not identified [49]. These latter authors reported that the oxidation onset temperature for $\mathrm{FOH} 28: 0$ was $245.74^{\circ} \mathrm{C}$, according to differential scanning calorimetry tests.

It has been proposed that the oxidation of fatty alcohols occurs through a first step where the corresponding aldehyde is formed, to afterwards being acetalized with the fatty alcohol yielding the hemiacetal, whose oxidation directly produces a wax ester, without the intervention of a fatty acid [50]. However, such reactions at room temperature need a catalyst [51]. According to the obtained results in this study, in the FDR samples, the wax ester content was $0.22 \mathrm{~g} / 100 \mathrm{~g}$, while for the Feed sample it was $0.11 \mathrm{~g} / 100 \mathrm{~g}(p<0.05)$. However, the contents of triglycerides $(4.21 \mathrm{~g} / 100 \mathrm{~g}$ vs. $4.34 \mathrm{~g} / 100 \mathrm{~g})$ and free fatty acids 
$(0.33 \mathrm{~g} / 100 \mathrm{~g}$ vs. $0.30 \mathrm{~g} / 100 \mathrm{~g})$ were not altered. The fact that the phytosterol content in FDR was $6.11 \mathrm{~g} / \mathrm{kg}$ and $6.52 \mathrm{~g} / \mathrm{kg}$ in Feed $(p>0.05)$ seems to indicate that oxidation reactions were not taking place. Moreover, in the assayed conditions, aldehydes were not detected, or any other degradation compounds related to fatty alcohols. Nevertheless, it could be hypothesized that, although octacosanal has a boiling point of $410{ }^{\circ} \mathrm{C}$, under the vacuum conditions carried out during the degassing step, it could evaporate. Thus, while FOH 28:0 disappeared, its oxidation intermediates would not be detected.

Alternatively, as farnesene and farnesol contents were slightly lower in the Feed samples than in the FDR samples, another explanation could be that the conditions assayed during the degassing step allowed the evaporation of some compounds, including FOH 28:0. Thus, this second explanation seems to be more likely, since according to previous information, $\mathrm{FOH}$ 28:0 is highly resistant to degradation, and this is only observed under harsh conditions.

After the degassing step, the obtained sample (i.e., Feed) was assayed in the spinning band. Under the tested conditions, a total of seven fractions (i.e., cuts) were collected but only those corresponding to $\mathrm{C} 6$ and $\mathrm{C} 7 \mathrm{did}$ not contain farnesene or farnesol isomers (Table 3). They were also the only distillates showing the presence of the target bioactive lipids: PR 30 (753.64 g/ $\mathrm{kg}$ in C6 and 634.20 g/ $\mathrm{kg}$ in C7, $p<0.05)$, FOH C28:0 (1.61 g/ $\mathrm{kg}$ in $\mathrm{C} 6$ and $3.88 \mathrm{~g} / \mathrm{kg}$ in $\mathrm{C} 7, p<0.05)$, and ST $(11.40 \mathrm{~g} / \mathrm{kg}$ in C6 and $30.84 \mathrm{~g} / \mathrm{kg}$ in C7, $p<0.05)$. Thus, $\mathrm{C} 6$ showed higher contents of PR 30 than $\mathrm{C} 7$, being the main compounds, triterpene IV $(438 \mathrm{~g} / \mathrm{kg}$ in C6 and $352 \mathrm{~g} / \mathrm{kg}$ in C7, $p<0.05)$, and triterpene VIII $(242 \mathrm{~g} / \mathrm{kg}$ in C6 vs. $230 \mathrm{~g} / \mathrm{kg}$ in C7). These two triterpene compounds (IV and VIII) were also the most relevant of this group in terms of concentration in the FDR sample. However, triterpenes II, V, and VII were only detected after distillation in C6 and C7 samples. They were probably present in the FDR sample but in concentrations below the LOD of the technique.

Regarding the ST moiety, the compound profile was the same in C6 and C7 and in agreement with that previously mentioned for FDR (i.e., ergosterol, campesterol, stigmasterol, and $\beta$-sitosterol). Regarding the profile of other lipid classes and other compounds detected by HPLC-ELSD (Table 4), the polymer was eliminated during the distillation process as well as monoglycerides.

\subsection{Stability of the Distillates Enriched in Bioactive Lipids}

The distillation procedure assayed on the Feed samples resulted into two fractions enriched in PR 30, and the potentially bioactive lipids FOH 28:0 and ST (i.e., C6 and C7). At this point, an accelerated stability study was conducted to observe possible alterations that these materials might undergo, with special interest in the mentioned bioactive lipids. The obtained data would help to understand potential applications of the distillates as functional ingredients.

According to the results obtained by FTIR-ATR (Figure 1), for the FDR and Feed samples, it was possible to verify a decrease in the intensity of the band at $2969-2849 \mathrm{~cm}^{-1}$ (-CH stretching, corresponding to aliphatic chains), accompanied by an increase in the intensity of the bands at $1108-1102$ and $1014 \mathrm{~cm}^{-1}\left(-\mathrm{CH}_{3}-\mathrm{CO}\right.$ rocking, corresponding to the ketone groups) from $\mathrm{T} 0$ to $\mathrm{T} 3$. These variations suggest that, during the stability test, the oxidation of farnesene to a ketone was occurring [52].

Moreover, for the $\mathrm{C} 6$ and $\mathrm{C} 7$ samples, the obtained spectra at $\mathrm{T} 0$ showed a vibration band at $1714-712 \mathrm{~cm}^{-1}$ (-OH bending) due to the presence of 1-octacosanol and phytosterols. The observations of two vibrational bands at $1671 \mathrm{~cm}^{-1}$ and $1641 \mathrm{~cm}^{-1}$ (-C=C-stretching vibration) and another band at $888 \mathrm{~cm}^{-1}\left(-\mathrm{CH}_{2}\right.$ out of plane deformation) indicate the presence of aliphatic unsaturated chains, probably associated with terpenes. Furthermore, the overlapping of T0, T1, T2, and T3 FTIR-ATR spectra for both samples (C6 and C7) showed that there were no changes in their physicochemical profiles throughout time. 
Table 3. Profile $(\mathrm{g} / \mathrm{kg})$ in terpenes, fatty alcohols, and phytosterols in distilled samples (C6 and C7) at the different assay times.

\begin{tabular}{|c|c|c|c|c|c|c|c|c|c|c|c|c|}
\hline \multirow{2}{*}{$\begin{array}{c}\text { C6 } \\
\text { Compound }\end{array}$} & \multicolumn{3}{|c|}{ T0 } & \multicolumn{3}{|c|}{ T1 } & \multicolumn{3}{|c|}{ T2 } & \multicolumn{3}{|c|}{ T3 } \\
\hline & Mean & & SD & Mean & & SD & Mean & & SD & Mean & & SD \\
\hline Sesterterpene (PR 25) & A 3.40 & \pm & 0.20 & $\mathrm{~A}_{3.38}$ & \pm & 0.24 & B 2.28 & \pm & 0.05 & B 2.15 & \pm & 0.21 \\
\hline Triterpene I (PR 30) & В 22.86 & \pm & 2.93 & A 29.15 & \pm & 0.60 & B 26.23 & \pm & 0.76 & B 24.35 & \pm & 0.26 \\
\hline Triterpene II (PR 30) & $C_{3.32}$ & \pm & 0.27 & B 4.57 & \pm & 0.28 & ${ }^{\mathrm{A}} 6.38$ & \pm & 0.54 & D 3.90 & \pm & 0.22 \\
\hline Triterpene III (PR 30) & В 33.36 & \pm & 3.74 & A 41.27 & \pm & 0.36 & В 36.79 & \pm & 1.29 & B 34.74 & \pm & 0.08 \\
\hline Triterpene IV (PR 30) & В 438.12 & \pm & 19.4 & A 504.66 & \pm & 0.44 & $C_{404.35}$ & \pm & 8.84 & $\mathrm{C}_{411.04}$ & \pm & 6.10 \\
\hline Triterpene V (PR 30) & C 5.82 & \pm & 0.25 & C 5.74 & \pm & 0.13 & A 14.26 & \pm & 1.23 & B 7.61 & \pm & 1.25 \\
\hline Triterpene VII (PR 30) & A 7.42 & \pm & 0.51 & A 7.90 & \pm & 0.51 & A 8.81 & \pm & 1.53 & B 6.50 & \pm & 0.03 \\
\hline Triterpene VIII (PR 30) & В 242.75 & \pm & 13.2 & A 282.45 & \pm & 3.14 & D 184.12 & \pm & 2.83 & $C_{22} 20.45$ & \pm & 8.02 \\
\hline$\Sigma$ TERPENES & B 757.05 & \pm & 40.5 & A 879.12 & \pm & 3.7 & $C_{680.93}$ & \pm & 17 & $\mathrm{C}_{710.74}$ & \pm & 13.1 \\
\hline 1-Octacosanol (FOH 28:0) & A 1.61 & \pm & 0.18 & B 1.49 & \pm & 0.06 & $\mathrm{C}<\mathrm{LOD}$ & & na & $C<$ LOD & & na \\
\hline$\sum \mathrm{FOH}$ & A 1.61 & \pm & 0.18 & B 1.49 & \pm & 0.06 & $C<$ LOD & & na & $C<$ LOD & & na \\
\hline Ergosterol (ST 28:3;O) & B 5.91 & \pm & 0.98 & A 9.93 & \pm & 0.28 & $C_{2.20}$ & \pm & 0.35 & $C_{2.51}$ & \pm & 0.21 \\
\hline Campesterol (ST 28:1;O) & $C_{1.64}$ & \pm & 0.01 & A 2.70 & \pm & 0.1 & B 2.01 & \pm & 0.33 & D 1.12 & \pm & 0.06 \\
\hline Stigmasterol (ST 29:2;O) & $\mathrm{C}_{1.67}$ & \pm & 0.06 & A 2.81 & \pm & 0.04 & B 2.30 & \pm & 0.01 & D 1.37 & \pm & 0.14 \\
\hline$\beta$-Sitosterol (ST 29:1;O) & B 2.18 & \pm & 0.25 & A 3.08 & \pm & 0.21 & $\mathrm{C}_{1.67}$ & \pm & 0.13 & $\mathrm{C}_{1.61}$ & \pm & 0.04 \\
\hline$\Sigma S T$ & B 11.40 & \pm & 1.27 & A 18.53 & \pm & 0.53 & C 8.18 & \pm & 0.82 & D 6.61 & \pm & 0.37 \\
\hline C7 & \multicolumn{3}{|c|}{ T0 } & \multicolumn{3}{|c|}{ T1 } & \multicolumn{3}{|c|}{ T2 } & \multicolumn{3}{|c|}{ T3 } \\
\hline Compound & Mean & & SD & Mean & & SD & Mean & & SD & Mean & & SD \\
\hline Triterpene I (PR 30) & C 9.80 & \pm & 1.19 & A 11.48 & \pm & 0.2 & C 9.67 & \pm & 0.54 & B 10.66 & \pm & 0.52 \\
\hline Triterpene II (PR 30) & $C_{6.65}$ & \pm & 0.91 & A 8.15 & \pm & 0.27 & $C_{6.82}$ & \pm & 0.2 & B 6.95 & \pm & 0.26 \\
\hline Triterpene III (PR 30) & D 20.30 & \pm & 2.13 & A 23.66 & \pm & 0.32 & $C_{21.08}$ & \pm & 0.34 & В 21.45 & \pm & 0.87 \\
\hline Triterpene IV (PR 30) & A 352.42 & \pm & 23.4 & A 383.56 & \pm & 1.47 & $C_{309.84}$ & \pm & 3.85 & В 328.42 & \pm & 5.28 \\
\hline Triterpene V (PR 30) & 9.41 & \pm & 0.90 & 9.61 & \pm & 0.25 & 9.95 & \pm & 0.91 & 9.76 & \pm & 0.34 \\
\hline Triterpene VII (PR 30) & 5.26 & \pm & 0.69 & 5.57 & \pm & 0.35 & 4.83 & \pm & 0.62 & 3.88 & \pm & 0.20 \\
\hline Triterpene VIII (PR 30) & B 230.35 & \pm & 13.1 & A 252.10 & \pm & 1.64 & D 195.89 & \pm & 6.00 & C 201.61 & \pm & 5.36 \\
\hline$\Sigma$ TERPENES & В 634.20 & \pm & 42.3 & A 694.14 & \pm & 3.74 & D 558.09 & \pm & 9.2 & C 582.73 & \pm & 9.08 \\
\hline 1-Octacosanol (FOH 28:0) & A 3.88 & \pm & 0.36 & B 3.42 & \pm & 0.03 & $C<$ LOD & & na & $\mathrm{C}<\mathrm{LOD}$ & & na \\
\hline$\Sigma \mathrm{FOH}$ & A 3.88 & \pm & 0.36 & B 3.42 & \pm & 0.03 & $C<$ LOD & & na & $\mathrm{C}<\mathrm{LOD}$ & & na \\
\hline Ergosterol (ST 28:3;O) & B 15.93 & \pm & 1.82 & A 18.95 & \pm & 0.28 & $\mathrm{C}_{11.21}$ & \pm & 0.82 & D 5.88 & \pm & 0.25 \\
\hline Campesterol (ST 28:1;O) & B 4.20 & \pm & 0.39 & A 5.11 & \pm & 0.27 & $C_{3.91}$ & \pm & 0.27 & D 2.83 & \pm & 0.07 \\
\hline Stigmasterol (ST 29:2;O) & B 4.63 & \pm & 0.45 & A 5.68 & \pm & 0.04 & $C_{3.85}$ & \pm & 0.33 & D 3.12 & \pm & 0.15 \\
\hline$\beta$-Sitosterol (ST 29:1;O) & B 6.08 & \pm & 0.79 & A 7.04 & \pm & 0.29 & $C_{4.50}$ & \pm & 0.05 & $C_{3.61}$ & \pm & 0.16 \\
\hline$\Sigma \mathrm{ST}$ & B 30.84 & \pm & 3.45 & A 36.77 & \pm & 0.64 & C 23.47 & \pm & 1.33 & D 15.44 & \pm & 0.38 \\
\hline
\end{tabular}

Results expressed as mean $\pm \mathrm{SD}(n=3)$. T0, time 0 (initial); T1, time 1st month; T2, time 2nd month; T3, time 3rd month end of study. FOH, fatty alcohols and ST, sterols. Different superscript letters in a row for significant differences during the assayed time $(p<0.05)$.

Regarding the lipid compositions of the C6 and C7 samples, during the accelerated study, it was found a decrease in the concentration of phytosterols (Table 4. For the C6 sample, the phytosterols content at T0 was $1.32 \mathrm{~g} / 100 \mathrm{~g}$ and at T3 it was $1.02 \mathrm{~g} / 100 \mathrm{~g}$ $(p<0.05)$. For the $\mathrm{C} 7 \mathrm{sample}$, the initial concentration (i.e., T0) was $3.40 \mathrm{~g}$ phytosterols $/ 100$ $\mathrm{g}$ and, at the end of the assayed sampling time, it was $2.89 \mathrm{~g}$ phytosterols $/ 100 \mathrm{~g}(p<0.05)$.

The decrease in phytosterol content mentioned above did not follow the same pattern for both distillates. For C6, the reduction was only significant after T1 (1.13 g phytosterols / $100 \mathrm{~g}$ in $\mathrm{T} 2$ samples), while for $\mathrm{C} 7$, the alteration was observed at the first sampling point (3.30 g phytosterols $/ 100 \mathrm{~g}$ in T1 samples). The reduction in phytosterol content also occurred in the FDR sample $(0.78 \mathrm{~g} / 100 \mathrm{~g}$ in T0 vs. $0.36 \mathrm{~g} / 100 \mathrm{~g}$ in T3, $p<0.05)$ and the Feed sample $(0.73 \mathrm{~g} / 100 \mathrm{~g}$ in T0 vs. $0.37 \mathrm{~g} / 100 \mathrm{~g}$ in T3, $p<0.05)$ (Table 4$)$. 
Table 4. Lipid class compositions (g/100 g of lipids) of distilled samples (C6 and C7) at the different assay times.

\begin{tabular}{|c|c|c|c|c|c|c|c|c|c|c|c|c|}
\hline \multirow{2}{*}{$\begin{array}{c}\text { C6 } \\
\text { Compound }\end{array}$} & \multicolumn{3}{|c|}{ T0 } & \multicolumn{3}{|c|}{ T1 } & \multicolumn{3}{|c|}{$\mathrm{T} 2$} & \multicolumn{3}{|c|}{ T3 } \\
\hline & Mean & & SD & Mean & & SD & Mean & & SD & Mean & & SD \\
\hline Hydrocarbons & C 90.93 & \pm & 0.64 & В 91.42 & \pm & 0.70 & A 92.68 & \pm & 0.23 & A 93.50 & \pm & 0.16 \\
\hline Wax esters & В 0.21 & \pm & 0.01 & ${ }^{\mathrm{A}} 0.42$ & \pm & 0.02 & В 0.24 & \pm & 0.12 & В 0.37 & \pm & 0.01 \\
\hline Triglycerides & A 0.98 & \pm & 0.10 & $\mathrm{~A}_{0.86}$ & \pm & 0.09 & В 0.73 & \pm & 0.03 & $C_{0.52}$ & \pm & 0.05 \\
\hline Fatty alcohols & A 3.11 & \pm & 0.24 & A 3.03 & \pm & 0.28 & B 2.60 & \pm & 0.12 & в 2.47 & \pm & 0.14 \\
\hline Phytosterols & A 1.31 & \pm & 0.10 & A 1.25 & \pm & 0.09 & В 1.13 & \pm & 0.01 & B 1.02 & \pm & 0.03 \\
\hline Diglycerides & A 3.01 & \pm & 0.08 & В 2.42 & \pm & 0.24 & В 2.41 & \pm & 0.05 & $C_{2.01}$ & \pm & 0.02 \\
\hline Free fatty acids & B 0.46 & \pm & 0.11 & A 0.60 & \pm & 0.09 & $\mathrm{C}_{0.21}$ & \pm & 0.01 & D 0.11 & \pm & 0.01 \\
\hline $\mathrm{C} 7$ & \multicolumn{3}{|c|}{ T0 } & \multicolumn{3}{|c|}{ T1 } & \multicolumn{3}{|c|}{ T2 } & \multicolumn{3}{|c|}{ T3 } \\
\hline Compound & Mean & & SD & Mean & & SD & Mean & & SD & Mean & & SD \\
\hline Hydrocarbons & C 85.81 & \pm & 0.31 & A 87.52 & \pm & 0.59 & B 87.79 & \pm & 0.25 & C 85.77 & \pm & 0.33 \\
\hline Wax esters & В 0.41 & \pm & 0.01 & ${ }^{\mathrm{A}} 0.52$ & \pm & 0.04 & $\mathrm{C}_{0.29}$ & \pm & 0.01 & B 0.46 & \pm & 0.01 \\
\hline Triglycerides & A 1.29 & \pm & 0.15 & A 0.98 & \pm & 0.05 & В 0.80 & \pm & 0.03 & B 0.78 & \pm & 0.01 \\
\hline Fatty alcohols & A 3.59 & \pm & 0.59 & A 3.39 & \pm & 0.03 & В 2.47 & \pm & 0.10 & В 2.34 & \pm & 0.07 \\
\hline Phytosterols & A 3.40 & \pm & 0.08 & В 3.30 & \pm & 0.06 & В 3.06 & \pm & 0.10 & $C_{2.89}$ & \pm & 0.07 \\
\hline Diglycerides & 4.68 & \pm & 1.09 & 4.35 & \pm & 0.32 & 5.42 & \pm & 0.08 & 5.76 & \pm & 0.21 \\
\hline Free fatty acids & В 0.82 & \pm & 0.04 & A 1.11 & \pm & 0.13 & В 0.46 & \pm & 0.01 & $C_{0.55}$ & \pm & 0.02 \\
\hline
\end{tabular}

Results expressed as mean $\pm \mathrm{SD}(n=3)$. T0, time 0 (initial); T1, time 1st month; T2, time 2nd month; T3, time 3rd month end of study. Different superscript letters in a row for significant differences during the assayed time $(p<0.05)$.

Due to the antioxidant properties of these compounds, such loss may indicate that oxidation reactions are taking place [49]. Phytosterols can be oxidized through auto- or photo-oxidation resulting in phytosterols oxidation products (POPs) [53]. On the one hand, these POPs can be nonpolar when derived by oxidation, dehydrogenation, or dehydration and, on the other hand, polar when derived by epoxidation, hydration, or interaction with oxygen or reactive free radicals. Possibly, for all these reactions, the target could be the steroid ring. Furthermore, Lengyel et al. [54] suggested that the position of the double bonds drastically affected the stability of the molecule since $\Delta 7$ sterols were more susceptible to oxidation attack than $\Delta 5$.

For all the assayed samples, the phytosterol fraction was composed of ergosterol, campesterol, stigmasterol, and $\beta$-sitosterol. In both the FDR and Feed samples, only ergosterol decreased at the end of the assayed time. In both distillates, all phytosterols were affected, but ergosterol showed the highest reduction rates (i.e., $57.48 \%$ in C6 and $63.08 \%$ in C7). Interestingly, these compounds have double bonds at positions 5 and 7 and these results seems to agree with the hypothesis proposed by Lengyel et al.

Some other lipids detected in the assayed samples are known to be prone to undergo oxidation or to be involved in lipid degradation as free fatty acids. Lipid peroxidation reactions have such compounds as substrates: during initiation, fatty acids are converted into lipid alkyl radicals that react with ${ }^{3} \mathrm{O}_{2}$ to yield lipid peroxy radical (i.e., propagation phase) to finally subtract a hydrogen to produce hydroperoxides [55]. These latter compounds can further be transformed into aldehydes, ketones, acids, esters, alcohols, and short-chain hydrocarbons.

The variations of free fatty acids from T0 to T1 were as follows: $0.46 \mathrm{~g} / 100 \mathrm{~g}$ vs. $0.60 \mathrm{~g} / 100 \mathrm{~g}$ in the C6 sample and $0.82 \mathrm{~g} / 100 \mathrm{~g}$ vs. $1.11 \mathrm{~g} / 100 \mathrm{~g}$ in the C7 sample $(p<0.05)$. Such increments were also detected in the FDR sample $(0.33 \mathrm{~g} / 100 \mathrm{~g}$ at T0 vs. $0.48 \mathrm{~g} / 100 \mathrm{~g}$ at T3, $p<0.05$ ) but not in the Feed sample. An explanation for this could be the hydrolysis of lipids presenting esterified fatty acids in their structure as triglycerides, diglycerides, or wax esters. However, in the case of the triglycerides, those changes only started after T1. It must be noted that as a result of oxidation, the fatty acid backbone of triglycerides can transform into hydroperoxides [48] and, afterwards, yield oxidized monomers, dimers, and oligomers in concentrations inversely correlated to those of free fatty acids [56]. 
Other study results have shown that the matrix plays an important role in the oxidative stability of lipids. On the one hand, in commercial infant formulas containing vegetable oils, changes in oxidation markers (i.e., oxidized triglyceride monomers and free fatty acids) were not detected over 4 years [57] or by accelerated storage [58]. On the other hand, studies conducted on crude palm oil stored for 12 months at $26-32{ }^{\circ} \mathrm{C}, 20-25{ }^{\circ} \mathrm{C}$, and $4-8{ }^{\circ} \mathrm{C}$ reported that acid value and peroxide value increased in all the assayed conditions due to microbiological growth and moisture, although those parameters were not determined [59]. Furthermore, when roasted coffee was monitored over 6 months, in the presence of air or nitrogen at $30^{\circ} \mathrm{C}$ or $5^{\circ} \mathrm{C}$, after the first month of storage, an increment in the concentration of free fatty acids was found that was consistent with triglycerides hydrolysis, and afterwards, a decrease during the assayed time as a result of oxidation [60]. This also agrees with studies conducted in rice bran (i.e., natural source of 1-octacosanol), where crude samples at $20-25{ }^{\circ} \mathrm{C}$ for 24 weeks showed free fatty acid increments above those observed when rice was processed using heating treatments [61]. Those authors hypothesized that heating inactivates residual enzymes (i.e., lipases).

Other glycerolipids that were detected in the assayed samples of this study were diglycerides. On the one hand, their contents remained unchanged in the C7 samples, although a slight increase was observed after T1 $(p>0.05)$ which seemed to be consistent with the hydrolysis of triglycerides. On the other hand, for C6 samples, the levels decreased significantly from T0 to T1 (3.01 g/100 g vs. $2.42 \mathrm{~g} / 100 \mathrm{~g})$ and remained constant during the two following sampling times, to decrease at T3 to $2.01 \mathrm{~g} / 100 \mathrm{~g}(p<0.05)$. The FDR and Feed samples showed reductions in diglycerides after T0.

Wax esters are lipids composed of a fatty acid esterified to a fatty alcohol. In the FDR and Feed samples, these lipids significantly decreased after T2. Interestingly, in both the C6 and C7 samples, the concentration of wax esters significantly increased from T0 to T1, decreased afterwards, and increased again in T3. As previously explained in the above sections, wax esters can be created through the oxidative degradation of 1-octacosanol [50]. Indeed, the concentration of 1-octacosanol changed in the C6 sample from $1.61 \mathrm{~g} / \mathrm{kg}$ at T0 to $1.49 \mathrm{~g} / \mathrm{kg}$ at T1 while it was not detected in the following sampling points. For the C7 sample, the concentration decreased from $3.88 \mathrm{~g} / \mathrm{kg}$ at T0 to $3.43 \mathrm{~g} / \mathrm{kg}$ at T1 and was also not detected at $\mathrm{T} 2$ or $\mathrm{T} 3$.

Therefore, the obtained results suggest that during the assayed accelerated storage test, for both $\mathrm{C} 6$ and $\mathrm{C} 7$ samples, oxidation reactions take place resulting in a complete loss of 1-octacosanol, which may be converted into wax esters, reduction in the phytosterol content, and a probable hydrolysis of triglycerides.

\subsection{Bioactivity Studies of C6 and C7 Samples}

The distilled samples, i.e., the C6 and C7 samples at the beginning and the end of the stability study, T0 and T3, respectively, were used to evaluate cytotoxicity on macrophages (Figure 2A,B, respectively). In both samples, no significative differences were observed between $\mathrm{T} 0$ and $\mathrm{T} 3$, which indicated that the samples did not degrade into toxic compounds with time. Sample C6 did not present cytotoxicity at any concentration tested. Although sample C6 at T0 showed lower values of metabolic inhibition than at T3, no conclusions could be made. The negative values of metabolic inhibition might indicate an increase in cellular proliferation; however, additional oriented studies should be conducted to pursue such a hypothesis. Sample C7 presented cytotoxicity at the highest concentration tested ( $5 \mathrm{mg} / \mathrm{mL}$ ) with no differences observed between T0 and T3 (Figure 2B).

The distilled samples, C6 and C7, at T0 and T3, at $2 \mathrm{mg} / \mathrm{mL}$, were used to evaluate cytokine production by macrophages under regular or inflammatory conditions (without and with LPS stimulus, respectively). In the Supplementary Materials the values of IL- $\beta$, IL-6, IL-8, and TNF- $\alpha$ normalized to total protein content are shown. For IL- $\beta$ and IL-8, no differences were observed under the conditions tested, although samples C6 at T0 and T3 and sample C7 at T0 did increase the concentration of IL-8 in macrophages under no stimulus. For IL-6 and TNF- $\alpha$, no differences were observed in macrophages without 
inflammatory stimulus. However, under LPS stimulation, all the samples tested lead to statistically significant decreases in TNF- $\alpha$ and IL-6 levels (C and D in Figure 3). There were no differences in anti-inflammatory activity found between $\mathrm{T} 0$ and $\mathrm{T} 3$ for both $\mathrm{C} 6$ and $\mathrm{C} 7$ distilled samples.

A

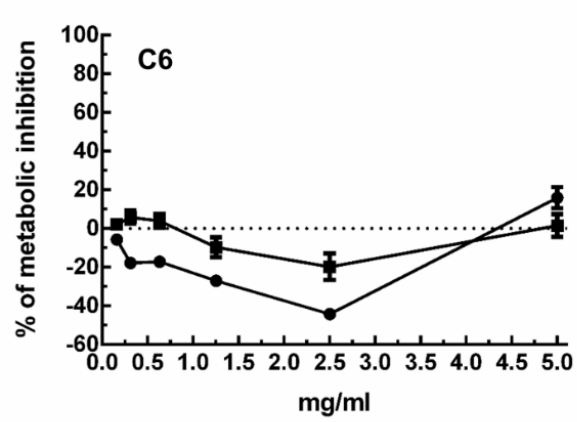

C

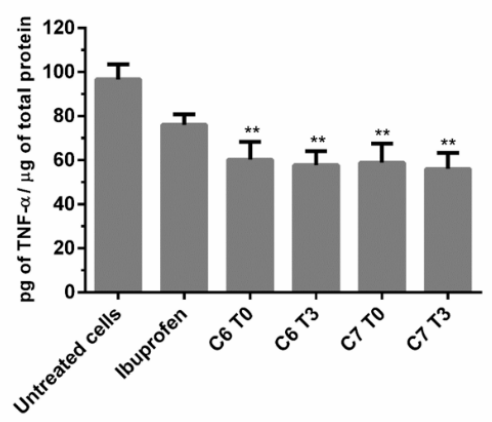

B

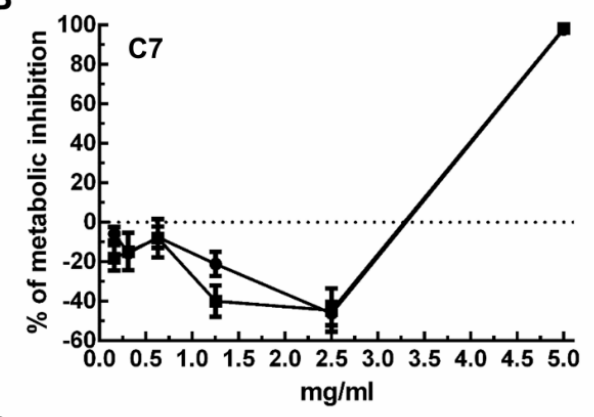

D

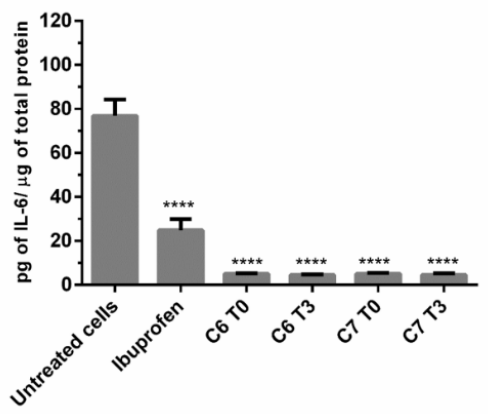

Figure 2. Effect of the distilled samples on macrophages. (A,B) Cytotoxicity evaluation of C6 and C7 by measuring the metabolic inhibition (PrestoBlue assay). Dots correspond to T0 samples and squares correspond to T3 samples (C,D) evaluation of TNF- $\alpha$ and IL-6 levels, respectively, in macrophages under an inflammatory stimulus (LPS). Values are expressed as pg of cytokine normalized to the total protein content. Ibuprofen at $1 \mathrm{mM}$ was used as an anti-inflammatory control. One-way ANOVA was used for statistical analysis. ${ }^{* *} p \leq 0.01 ; * * * p \leq 0.0001$.
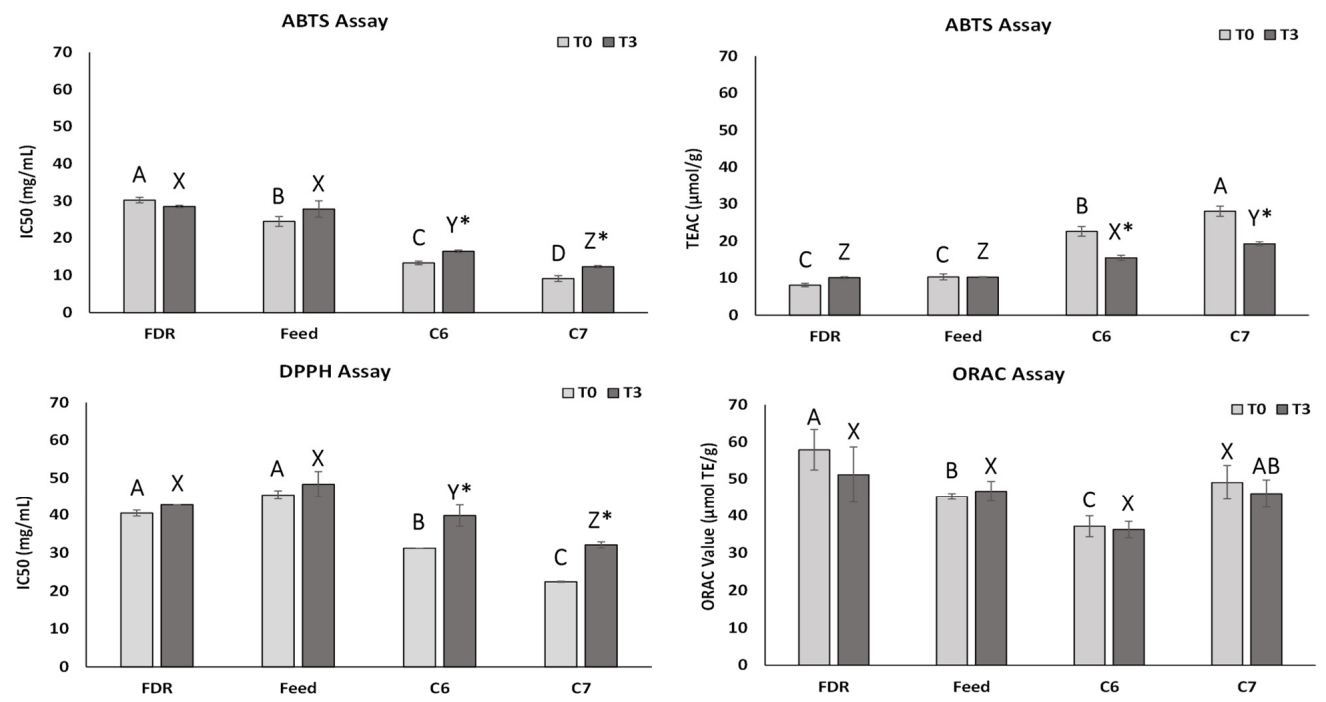

Figure 3. Antioxidant values determined by ABTS, DPPH, and ORAC assays for the FDR, Feed, C6, and C7 samples over the accelerated stability storage (T0 vs. T3). A,B,C letters on top of bars for significant differences $(p<0.05)$ among samples at T0. $X, Y, Z$ for significant differences $(p<0.05)$ at T3. ${ }^{*}$ significant differences $(p<0.05)$ along time for a same sample (i.e., T0 vs. T3). 
The influence of the lipidic extracts resulting from distillation of samples C6 and C7 were analyzed in macrophages. Contrary to the Feed sample which was highly cytotoxic to cells (i.e., 100\% metabolic inhibition at any assayed concentration independent of sampling at T0 or T3), both C6 and C7 samples presented no toxicity, up to 5 and $2.5 \mathrm{mg} / \mathrm{mL}$, respectively. Furthermore, the analysis of cytokine production in the absence and the presence of an inflammatory stimulus (LPS) revealed that both samples strongly decreased the levels of TNF- $\alpha$ and IL- 6 , which demonstrated a possible anti-inflammatory activity by these extracts. The anti-inflammatory capacity of most of the constituents identified in these extracts have already been described elsewhere $[30,62,63]$. Nevertheless, the reported results also show that these extracts present a high level of stability over time with respect to anti-inflammatory activity. Although the levels of fatty alcohols and sterols change with time, the capacity of these extracts to decrease the levels of TNF- $\alpha$ and IL- 6 in an inflammation context is retained.

\subsection{Changes in Antioxidant Activity of the Assayed Samples during the Stability Test}

The obtained results regarding the antioxidant performance of samples by the DPPH, ABTS, and ORAC assays are represented in Figure 3.

The values obtained for the DPPH assay showed that the C6 and C7 samples presented higher antioxidant activity than the Feed and FDR samples at the T0 sampling time, since these last two samples had higher $\mathrm{IC}_{50}$ values $(p<0.05)$. The antioxidant activities of the C6 and C7 samples were slight reduced during the stability test $(p<0.05)$, which were probably related to decreases in phytosterol content in these samples from $\mathrm{T} 0$ to $\mathrm{T} 3$, therefore, suggesting that those changes are related to oxidation reactions. This behavior is reflected by an increase in the $\mathrm{IC}_{50}$ values (from $31.26 \pm 0.12 \mathrm{mg} / \mathrm{mL}$ at T0 to $39.87 \pm 2.81 \mathrm{mg} / \mathrm{mL}$ at T3 and from $22.43 \pm 0.17 \mathrm{mg} / \mathrm{mL}$ at T0 to $32.12 \pm 0.79 \mathrm{mg} / \mathrm{mL}$ at $\mathrm{T} 3$, respectively, for the C6 and C7 samples). The FDR and Feed antioxidant activities did not change significantly during the stability test.

In a similar way to the DPPH assay, the ABTS test results showed that the C6 and C7 samples presented higher antioxidant activity than the Feed and FDR samples at T0. On the one hand, the ABTS values indicated that the distillates had a slight decrease in antioxidant activity from $\mathrm{T} 0$ to $\mathrm{T} 3$, established by an increase in the $\mathrm{IC}_{50}$ values (from $13.35 \pm 0.51 \mathrm{mg} / \mathrm{mL}$ at T0 to $16.47 \pm 0.34 \mathrm{mg} / \mathrm{mL}$ at T3 and from $9.16 \pm 0.78 \mathrm{mg} / \mathrm{mL}$ at $\mathrm{T} 0$ to $12.30 \pm 0.31 \mathrm{mg} / \mathrm{mL}$ at T3, respectively, for the $\mathrm{C} 6$ and $\mathrm{C} 7$ samples). As mentioned before, these differences between $\mathrm{T} 0$ and $\mathrm{T} 3$ are probably related to a decrease in the phytosterol content in these samples. On the other hand, the FDR and Feed antioxidant activities did not vary at the different assay times.

Considering the ORAC values of all assayed samples, these did not change over time $(37.15 \mu \mathrm{mol} \mathrm{TE} / \mathrm{g}$ at T0 vs. $36.25 \mu \mathrm{mol} \mathrm{TE} / \mathrm{g}$ at T3, $49.07 \mu \mathrm{mol} \mathrm{TE} / \mathrm{g}$ vs. $46.03 \mu \mathrm{mol}$ $\mathrm{TE} / \mathrm{g}, 45.24 \mu \mathrm{mol} \mathrm{TE} / \mathrm{g}$ vs. $46.65 \mu \mathrm{mol} \mathrm{TE} / \mathrm{g}$ and $57.87 \mu \mathrm{mol} \mathrm{TE} / \mathrm{g}$ vs. $51.17 \mu \mathrm{mol} \mathrm{TE} / \mathrm{g}$, respectively, for the $\mathrm{C} 6, \mathrm{C} 7$, Feed and FDR samples).

Therefore, after distillation, the obtained material (C6 and C7 samples) showed higher antioxidant capacity than the starting materials (FDR and Feed samples).

\subsection{Crystallization, Melting, and Decomposition Temperature}

The measured melting and crystallization temperatures for the FDR and Feed samples at T0, were $44.1^{\circ} \mathrm{C}$ and $39.4{ }^{\circ} \mathrm{C}$ and $40.9{ }^{\circ} \mathrm{C}$ and $29.6{ }^{\circ} \mathrm{C}$, respectively (Table 5). The fact that these transitions were not detected at $\mathrm{T} 1, \mathrm{~T} 2$, and $\mathrm{T} 3$ sampling times, may be due to the decreasing amounts of farnesene, fatty alcohol, and wax esters, previously discussed in the above section.

Interestingly, the enthalpy values involved in both transitions (melting and crystallization) were slightly lower in the Feed sample than that of the FDR sample, i.e., melting enthalpy was $6.4 \mathrm{~J} / \mathrm{g}$ FDR and $4.3 \mathrm{~J} / \mathrm{g}$ Feed while for crystallization was $4.7 \mathrm{~J} / \mathrm{g}$ FDR vs. $1.6 \mathrm{~J} / \mathrm{g}$ Feed. These results suggest that the slight differences regarding composition found for these two samples affected their thermal characteristics. 
Furthermore, the DSC analysis revealed that both samples, FDR and Feed, decomposed at $400.5^{\circ} \mathrm{C}$ and $400.7^{\circ} \mathrm{C}$, respectively. On the one hand, the decomposition temperatures did not vary significantly during the stability test, i.e., $403.9^{\circ} \mathrm{C}$ for the FDR sample and $399.4^{\circ} \mathrm{C}$ for the Feed sample. On the other hand, the enthalpy values presented for this transition were quite variable, i.e., from $317.2 \mathrm{~J} / \mathrm{g}$ to $553.9 \mathrm{~J} / \mathrm{g}$ for the FDR sample and from $348.4 \mathrm{~J} / \mathrm{g}$ to $409.7 \mathrm{~J} / \mathrm{g}$ for the Feed sample.

Regarding the distilled samples, the DSC analyses (Table 5) showed that the C7 sample presented higher crystallization and melting temperatures than that of the C6 sample (crystallization temperatures of 28.6 vs. $37.2{ }^{\circ} \mathrm{C}$ and melting temperatures of $41.5^{\circ} \mathrm{C}$ vs. $46.4^{\circ} \mathrm{C}$, for $\mathrm{C} 6$ vs. C7, respectively). According to the characterization obtained by GC-MS (Table 3), this was probably due to the higher concentration of 1-octacosanol and phytosterols (heavier compounds) in the C7 sample. These properties (crystallization and melting temperatures) did not show much alteration during the tested time (i.e., from $\mathrm{T} 0$ to T3): $\mathrm{C} 6$ crystallization and melting temperatures varied from $28.6^{\circ} \mathrm{C}$ to $26.7^{\circ} \mathrm{C}$ and from $41.5^{\circ} \mathrm{C}$ to $35.4{ }^{\circ} \mathrm{C}$, respectively, from $\mathrm{T} 0$ to $\mathrm{T} 3 ; \mathrm{C} 7$ crystallization and melting temperatures varied from $37.2{ }^{\circ} \mathrm{C}$ to $35.8^{\circ} \mathrm{C}$ and from $46.4^{\circ} \mathrm{C}$ to $44.2{ }^{\circ} \mathrm{C}$, respectively, from $\mathrm{T} 0$ to $\mathrm{T} 3$.

Table 5. Thermal characteristics (temperatures and enthalpies) of the study samples throughout the stability test.

\begin{tabular}{|c|c|c|c|}
\hline \multirow[b]{2}{*}{ FDR } & \multicolumn{3}{|c|}{ Temperature $\left({ }^{\circ} \mathrm{C}\right)(|\Delta \mathrm{H}|(\mathrm{J} / \mathrm{g}))$} \\
\hline & Crystallization & Melting & Decomposition \\
\hline T0 & $40.9(4.7)$ & $44.1(6.4)$ & $400.5(553.9)$ \\
\hline $\mathrm{T} 1$ & na & na & $401.5(317.2)$ \\
\hline $\mathrm{T} 2$ & na & na & $408.1(536.5)$ \\
\hline T3 & na & na & $403.9(324.1)$ \\
\hline \multicolumn{4}{|c|}{ Temperature $\left({ }^{\circ} \mathrm{C}\right)(|\Delta \mathrm{H}|(\mathrm{J} / \mathrm{g}))$} \\
\hline Feed & Crystallization & Melting & Decomposition \\
\hline T0 & $29.6(1.6)$ & $39.4(4.3)$ & $400.7(373.5)$ \\
\hline $\mathrm{T} 1$ & na & na & $399.2(348.4)$ \\
\hline $\mathrm{T} 2$ & na & na & $399.4(409.7)$ \\
\hline T3 & na & na & $399.2(295.7)$ \\
\hline \multicolumn{4}{|c|}{ Temperature $\left({ }^{\circ} \mathrm{C}\right)(|\Delta \mathrm{H}|(\mathrm{J} / \mathrm{g}))$} \\
\hline C6 & Crystallization & Melting & Decomposition \\
\hline T0 & $28.6(2.6)$ & $41.5(2.7)$ & $365.3(215.5)$ \\
\hline $\mathrm{T} 1$ & $28.3(2.2)$ & $39.3(2.2)$ & $383.9(180.8)$ \\
\hline $\mathrm{T} 2$ & $27.1(2.2)$ & $37.9(2.3)$ & $374.5(172.9)$ \\
\hline T3 & $26.7(1.8)$ & $35.4(1.7)$ & $373.5(137.2)$ \\
\hline \multicolumn{4}{|c|}{ Temperature $\left({ }^{\circ} \mathrm{C}\right)(|\Delta \mathrm{H}|(\mathrm{J} / \mathrm{g}))$} \\
\hline $\mathrm{C} 7$ & Crystallization & Melting & Decomposition \\
\hline T0 & $37.2(5.3)$ & $46.4(5.4)$ & $370.9(297.3)$ \\
\hline $\mathrm{T} 1$ & $39.3(4.4)$ & $47.4(4.7)$ & $377.4(117.9)$ \\
\hline $\mathrm{T} 2$ & $38.2(3.7)$ & $47.6(5.4)$ & $371.6(158.2)$ \\
\hline T3 & $35.8(4.1)$ & $44.2(3.4)$ & $371.8(166.3)$ \\
\hline
\end{tabular}

na, not available.

Finally, regarding the decomposition temperatures of samples $\mathrm{C} 6$ and $\mathrm{C} 7$ during the stability test, the values were from $365.3^{\circ} \mathrm{C}$ at $\mathrm{T} 0$ to $383.9^{\circ} \mathrm{C}$ at $\mathrm{T} 3$ and from $370.9^{\circ} \mathrm{C}$ at $\mathrm{T} 0$ to $377.4^{\circ} \mathrm{C}$ at T3, for the $\mathrm{C} 6$ and $\mathrm{C} 7$ samples, respectively. Similar to what happened with the FDR and Feed samples, the enthalpy values associated with the decomposition process ranged from $172.9 \mathrm{~J} / \mathrm{g}$ to $215.5 \mathrm{~J} / \mathrm{g}$ for the $\mathrm{C} 6$ sample and from $117.9 \mathrm{~J} / \mathrm{g}$ to $297.3 \mathrm{~J} / \mathrm{g}$ for the $\mathrm{C} 7$ sample. 


\section{Materials and Methods}

\subsection{Materials and Chemicals}

Farnesene distillation residue (FDR, collected in January 2020), a biowaste of the fermentative production of $\beta$-farnesene, was kindly donated by Amyris Inc., (Campinas, Brazil). Feed (FDR after pretreatment for distillation) and the distillates of interest (Cut 6 (C6) and Cut 7 (C7)) were also assayed.

For the HPLC assays, the mobile phases were prepared with the following solvents: 2-propanol (LC-MS grade $\geq 99.9 \%$ ), isooctane (HPLC grade $\geq 99.8 \%$ ) purchased from VWR Chemicals (Radnor, PA, USA), acetone (AcO) (HPLC grade $\geq 99.8 \%$ ) purchased from Thermo Fisher Scientific (Waltham, MA, USA), ethyl acetate (EtAc) (HPLC grade $\geq 99.7 \%$ ), water (for HPLC) purchased from Honeywell (Charlotte, NC, USA), acetic acid (HPLC grade $\geq 99.8 \%$ ) purchased from Carlo Erba Reagents (Barcelona, Spain), and triethylamine (TEA) (grade $\geq 99.5 \%$ ) purchased from Merck (Darmstadt, Germany). The samples were dissolved in dichloromethane (DCM) (HPLC grade $\geq 99.9 \%$ ) from VWR Chemicals (Radnor, PA, USA).

For the GC-MS analysis, the internal analytical standard dodecane (99\%) and the derivatizing reagent $\mathrm{N}, \mathrm{O}$-bis(trimethylsilyl)trifluoroacetamide with $1 \%$ trimethylchlorosilane (BSTFA) were purchased from Merk (Darmstadt, Germany).

Regarding the antioxidant assays, a phosphate buffer solution $(75 \mathrm{mM}, \mathrm{pH} 7.4)$ was prepared by using the salt solution of sodium dihydrogen phosphate $\left(\mathrm{NaH}_{2} \mathrm{PO}_{4}\right)$ anhydrous, $\geq 98 \%$ assay, purchased from Merk (Darmstadt, Germany).

Trolox ${ }^{\circledR}$ (6-hydroxy-2,5,7,8-tetramethylcroman-2-carboxilic acid) was used as radical scavenging and antioxidant standard, obtained from Merk (Darmstadt, Germany) with $\geq 97 \%$ assay. Stock methanolic solution of $\mathrm{DPPH}^{\bullet}\left(2,2^{\prime}\right.$-diphenyl-1-picrylhydrazyl) was prepared using $\mathrm{DPPH}^{\bullet}(95 \%)$, from Thermo Fisher Scientific (Waltham, MA, USA), and the final $\mathrm{DPPH}^{\bullet}$ concentration was determined spectrophotometrically (final absorbance of $0.600 \pm 0.100$ at $515 \mathrm{~nm})$. The ABTS diammonium salt (2,2'-azinobis(3-ethylbenzothiazoline6-sulfonic acid) ( $\geq 98 \%$ ), purchased from Merk (Darmstadt, Germany), was dissolved in ultrapure water and oxidized by aqueous solution of potassium persulfate $\left(\mathrm{K}_{2} \mathrm{O}_{8} \mathrm{~S}_{2}\right)$ $\geq 99.0 \%$, purchased from Merk (Darmstadt, Germany). The mixture was protected from light and mixed for $16 \mathrm{~h}$ in order to obtain the radical cation $\mathrm{ABTS}^{\bullet+}$.

For the ORAC measurements, the free radical initiator 2,2'-azobis-(2-methylpropionamidine) dihydrochloride (AAPH) (97\%) was obtained from Merk (Darmstadt, Germany) as well as fluorescein disodium salt used as a fluorescent probe.

\subsection{Distillation}

Initially, $500 \mathrm{~g}$ of the FDR sample was degassed under vacuum, for $30 \mathrm{~min}$, as a sample pretreatment, in order to eliminate water and possible gases, named the Feed sample. The recovery of target compounds was performed in a Mini Fractional Crude Oil Distillation system (B/R Instrument Corporation, Easton, PA, USA) under 0.5-0.8 Torr. The fractionation experiment was conducted with $480 \mathrm{~g}$ of Feed, placed in a round flask and attached to the system. The first fraction started to distillate at $250^{\circ} \mathrm{C}$, then, the temperature was increased to $265^{\circ} \mathrm{C}$, and the content was collected. A 10-minute equilibration step was performed and followed by a new temperature increase until the next fraction started to distillate. All fractions were collected in tared round glass flasks.

A total of 7 distillates were collected and labeled as Cut 1 to 7 (C1 to C7). Samples $\mathrm{C} 6$ and $\mathrm{C} 7$ were selected for further studies. Those samples were obtained at temperature intervals of $375-410{ }^{\circ} \mathrm{C}$ and $410-425^{\circ} \mathrm{C}$, respectively.

\subsection{Accelerated Stability Test}

In order to evaluate the stability of the mentioned samples under the influence of environmental factors such as temperature and humidity, an accelerated stability test was conducted at $50{ }^{\circ} \mathrm{C}$ and $75 \%$ of humidity conditions, according to the guidelines of the European Medicines Agency [64]. 
The FDR, Feed, C6, and C7 samples were weighed $(50 \mathrm{mg})$ in triplicate and placed into separated vials. The vials designated as $\mathrm{T} 0$ were collected and stored at $-80^{\circ} \mathrm{C}$ for further analysis. The remaining vials were placed into a desiccator, in which the desiccant salt was replaced by a saturated aqueous solution of sodium chloride in order to maintain the humidity at $75 \%$ [65]. The desiccator was covered and kept in an oven at $50{ }^{\circ} \mathrm{C}$, for 3 months.

After the first month, the vials identified as T1 were collected, purged with nitrogen, and stored at $-80^{\circ} \mathrm{C}$. At the end of the second and third months, the same procedure was repeated for the vials identified as $\mathrm{T} 2$ and $\mathrm{T} 3$, respectively.

All samples were characterized as to their composition (HPLC-ELSD and GC-MS), physicochemical profile (FTIR-ATR), thermal properties (DSC), as well as antioxidant and anti-inflammatory activity (the latter activities were performed only for T0 and T3 sampling times).

\subsection{HPLC-ELSD Analyses}

The samples were accurately weighed and dissolved in dichloromethane at a concentration of $3 \mathrm{mg} / \mathrm{mL}$. Then, samples were analyzed on an HPLC (model 1260 Infinity II, Agilent Technologies, Santa Clara, CA, USA) attached to an Evaporative Light Scattering Detector (ELSD, 1290 Infinity II, Agilent Technologies, Santa Clara, CA, USA) using nitrogen as nebulizing gas coupled to a Zorbax RX-SIL column $(2.1 \times 150 \mathrm{~mm}, 5 \mu \mathrm{m}$, Agilent Technologies, Santa Clara, CA, USA). The analysis conditions were assayed, as described by Abreu et al. [66], with slight changes (please see Supplementary Materials data. The compositions of the mobile phases were as follows: (A) isooctane/ethyl acetate (99.8:0.2, $v / v) ;(\mathrm{B})$ acetone/ethyl acetate $(2: 1, v / v)$ containing $0.1 \%$ acetic acid $(v / v) ;(\mathrm{C})$ 2-propanol/water $(85: 15, v / v)$ containing $0.013 \%$ acetic acid $(v / v)$ and $0.031 \%$ of TEA $v / v$; (D) EtAc. The flow rate was set at $0.275 \mathrm{~mL} / \mathrm{min}$ and an injection volume of $20 \mu \mathrm{L}$. The detector was set as follows: evaporator and nebulizer temperature set at $60{ }^{\circ} \mathrm{C}$ with nitrogen as nebulizing gas at 1.20 SLM flow rate. For the determination of elution order, pure standards were injected as well as available bibliography was used [67]. In all analyses performed, all the samples were injected at least in triplicate.

\subsection{GC-MS Analyses}

The samples were previously derivatized into their trimethylsilyl derivatives (TMS). Thus, in a glass vial, $5 \mathrm{mg}$ of lipid extract were accurately weighted and added with $100 \mu \mathrm{L}$ dodecane $(2.5 \mathrm{mg} / \mathrm{mL}$ in DCM $), 30 \mu \mathrm{L}$ of BSTFA and DCM to a final volume of $1.3 \mathrm{~mL}$. The mixture was incubated for $60 \mathrm{~min}$ at $30^{\circ} \mathrm{C}$.

Derivatized samples were analyzed on a GC-QqQ model EVOQ (Bruker, Karlsruhe, Germany) mass spectrometer, with a Rxi-5Sil MS column $(30 \mathrm{~m} \times 250 \mu \mathrm{m} \times 0.25 \mu \mathrm{m}$ nominal) at constant flow of $1 \mathrm{~mL} / \mathrm{min}$. The carrier gas used was helium and the operating conditions were as described by Attard et al. [45], with some modifications. The injector was set at $340{ }^{\circ} \mathrm{C}$ with a spilt 10 , and the oven temperature started at $60^{\circ} \mathrm{C}$ with a hold for $1 \mathrm{~min}$, then, the temperature was increased at $5^{\circ} \mathrm{C} / \mathrm{min}$ until $340{ }^{\circ} \mathrm{C}$ and maintained for $10 \mathrm{~min}$. The mass spectrometer detector was operated in electron ionization mode (EI) at $70 \mathrm{eV}$, a source temperature of $280^{\circ} \mathrm{C}$, the transfer line at $300^{\circ} \mathrm{C}$, and a quadrupole in a scan range from 33 to 1000 amu per second. The compound identification was based on the comparison of the obtained mass spectra with the information on the NIST library (v. 2.3) as well as by comparison with reference compounds.

To calculate the limits of detection (LOD) and quantification (LOQ), a calibration curve of dodecane was prepared in triplicate as TMS assaying concentrations in the range from 0.020 to $1 \mathrm{mg} / \mathrm{mL}$. $\mathrm{R}^{2}$ was 0.999 , LOD was $24 \mu \mathrm{g} / \mathrm{g}$, and LOQ was $74 \mu \mathrm{g} / \mathrm{g}$. For all the analyses, all samples were injected at least in triplicate. 


\subsection{Fourier Transform Infrared Spectroscopy with Attenuated Total Reflectance (FTIR-ATR)}

The samples were analyzed on a PerkinElmer Paragon 1000 FTIR (Waltham, MA, USA) with an ATR accessory (Diamond/ZnSe). The spectra were obtained in the wavenumber range of 4000-550 $\mathrm{cm}^{-1}$, with a resolution of $4 \mathrm{~cm}^{-1}$, by accumulating 16 scans. The FTIRATR vibrational bands were identified based on the literature [68] and are summarized in the Supplementary Materials (Table S2).

\subsection{Cell Culture}

The human monocytic cell line THP-1 (ATCC TIB-202) was kept in culture in RPMI media (Gibco) supplemented with 10\% FBS (Gibco), 1\% antibiotic (Gibco), and $50 \mathrm{mM}$ of beta-mercaptoethanol (Gibco) at $37{ }^{\circ} \mathrm{C}$, with $5 \% \mathrm{CO}_{2}$ in a humidified atmosphere. For the experiments, the THP- 1 cells were seeded according to the respective plate and differentiated into macrophages by treatment with $50 \mathrm{nM}$ of phorbol 12-myristate 13-acetate (PMA, Sigma, St. Louis, MO, USA, EUA) for $48 \mathrm{~h}$.

\subsection{Cytotoxicity Assays}

Cytotoxicity of lipidic extracts on macrophages were evaluated using a PrestoBlue assay (Thermo Fischer), according to the manufacturer's instructions. The THP-1 cells were seeded, at $1 \times 10^{4}$ cells/well, in 96-well plates and differentiated into macrophages. Then, cells were exposed to the lipidic extracts at different concentrations for $24 \mathrm{~h}$, in quadruplicates. Wells with media supplemented with lipidic extracts (without cells) were used to subtract a possible influence of the samples in the PrestoBlue fluorescence signal. Cells treated with 10\% DMSO were used as a negative control. After incubation, PrestoBlue reagent was added to the media and incubated for $2 \mathrm{~h}$. The fluorescence signal was read in a Synergy $\mathrm{H} 1$ microplate reader (BioTek). The results are expressed in percentage of metabolic inhibition as compared with a control (cells without treatment). At least two independent experiments were performed.

\subsection{Immune Response}

The THP- 1 cells, seeded at $3 \times 10^{5}$ cells/well in 24 -well plates, were differentiated into macrophages. Cells were treated for $24 \mathrm{~h}$ with the lipidic extracts at $2 \mathrm{mg} / \mathrm{mL}$ in the presence or absence of lipopolysaccharides from Escherichia coli O111:B4 (LPS, Sigma) at $1 \mu \mathrm{g} / \mathrm{mL}$ to induce inflammation. For anti-inflammatory control, cells were treated with $1 \mathrm{mM}$ of Ibuprofen (Mylan). Medium supernatants were collected and used to evaluate the levels of proinflammatory cytokines IL-6, IL- 8 , TNF- $\alpha$, and IL- $\beta$ by ELISA (Biolegend, San Diego, CA, USA). Cells were lysed with water and used for protein quantification via BCA method (Thermo Fischer, Waltham, MA, USA, EUA). The results were expressed in pg of cytokine $/ \mu \mathrm{g}$ of total protein. At least two independent experiments were performed.

\subsection{Antioxidant Activity}

For the DPPH microplate method, the free radical scavenging activity was determined spectrophotometrically. The 2,2'-diphenyl-picrylhydrazyl radical ( $\mathrm{DPPH}^{\bullet}$ ) analysis conditions were performed in a Greiner Bio-One transparent 96-well microplate (North Carolina, USA) and assayed as described by Bobo-García et al. [69], with some modifications. Samples were prepared from a stock solution $(40 \mathrm{mg} / \mathrm{mL})$ with consequent several dilutions from 28.00 to $0.88 \mathrm{mg} / \mathrm{mL}$ in methanol. The stock solution was submitted to ultrasounds (10 $\mathrm{min}$ ) in order to improve the dissolution, and then filtered using Macherey-Nagel $0.45 \mu \mathrm{m}$ pore size Chromafil ${ }^{\circledR}$ PET filters (Düren, Germany). The absorbance of the mixture from a stable violet at $515 \mathrm{~nm}$ to yellow after the addition of different quantities of sample/standard was measured. Trolox $(0.0075-0.075 \mathrm{mg} / \mathrm{mL})$ was used as antioxidant standard. A total of $25 \mu \mathrm{L}$ of the sample, standard or methanol (negative control), was added in each well separately to $175 \mu \mathrm{L}$ of DPPH ${ }^{\bullet}$ methanolic solution $(60 \mu \mathrm{M})$ and shaken for $5 \mathrm{~s}$ in the Synergy $\mathrm{H}^{\mathrm{TM}}$ microplate reader (BioTek Instruments, Inc.). After $30 \mathrm{~min}$ 
incubation period at $23^{\circ} \mathrm{C}$ kept in the dark, the absorbance was measured at $515 \mathrm{~nm}$ on a Synergy ${ }^{\mathrm{TM}}$ microplate reader, and the experiment was carried out in triplicate.

The inhibition capacity expressed as $I C_{50}$ values indicate the concentration of the antiradical compound necessary to decrease $50 \%$ of the initial $\mathrm{DPPH}^{\bullet}$ absorbance and was calculated using the linear regression from the concentration of sample versus percentage of inhibition [70]. To calculate the scavenging capability of DPPH radical, both $\mathrm{DPPH}^{\bullet}$ percentage $(\%)$ of inhibition and $I C_{50}$ were calculated by the following equations, respectively:

$$
\begin{gathered}
\% \text { Inhibition }=\frac{A_{\text {negative control }}-A_{\text {sample }}}{A_{\text {negative control }}} \times 100 \\
I C_{50}(\mathrm{mg} / \mathrm{mL})=\frac{50-b}{m}
\end{gathered}
$$

The ABTS assay was performed in a Greiner Bio-One transparent 96-well microplate (Kremsmünster, Austria), based on the inhibition by antioxidants of the absorbance of the radical cation 2,2-azinobis-(3-ethylbenzothiazoline-6-sulphonate) $\left(\mathrm{ABTS}^{\bullet+}\right)$, which has a characteristic wavelength absorption spectrum at $734 \mathrm{~nm}$ [71].

The samples used in this method were prepared the same as for the $\mathrm{DPPH}^{\bullet}$ method mentioned above and the analysis conditions were assayed as described by Benteldjoune et al. [72], with some modifications. Briefly, the $20 \mu \mathrm{L}$ of sample, standard or methanol (negative control), was added in each well separately and allowed to react with $180 \mu \mathrm{L}$ of ABTS $^{\bullet+}$ solution (prepared in methanol to an absorbance of $0.700 \pm 0.02$ at $734 \mathrm{~nm}$ ) for $5 \mathrm{~min}$ in the dark and the absorbance was immediately recorded at $734 \mathrm{~nm}$ by a Synergy $\mathrm{H} 1^{\mathrm{TM}}$ microplate reader (BioTek Instruments, Inc.) and the experiment was carried out in triplicate. Trolox diluted in phosphate buffer was used as the antioxidant standard $(25-175 \mu \mathrm{M})$. The Trolox equivalent antioxidant capacity (TEAC) was calculated using the following equation:

$$
\text { TEAC }(u \mathrm{~mol} / \mathrm{g})=\frac{\left(\frac{\left(I \%_{\text {sample }}-b\right)}{a} \times 10^{6}\right)}{C_{\text {Sample }} \times M_{\text {Trolox }}}
$$

To perform the ORAC microplate method, samples were prepared from a stock solution $(2.5 \mathrm{mg} / \mathrm{mL})$ with consequent several dilutions from 2.00 to $0.06 \mathrm{mg} / \mathrm{mL}$ in a phosphate buffer (PBS) (75 mM, pH 7.4). The stock solution was submitted to ultrasounds (10 $\mathrm{min}$ ) in order to improve the dissolution and then filtered using Macherey-Nagel $0.45 \mu \mathrm{m}$ pore size Chromafil ${ }^{\circledR}$ PET filters (Düren, Germany). The analysis conditions were assayed as described by Dávalos et al. [73] with some modifications. In a Thermo Fisher 96-well black microplate (Waltham, MA, USA), a volume of $20 \mu \mathrm{L}$ of the diluted sample, standard or PBS (negative control), was added in each well separately with $120 \mu \mathrm{L}$ of fluorescein $(116.66 \mathrm{nM})$, and then the microplate was preincubated at $37^{\circ} \mathrm{C}$ for $10 \mathrm{~min}$. After incubation, $60 \mu \mathrm{L}$ of 2,2'-azobis-(2-methylpropionamidine) dihydrochloride (AAPH) at $13.02 \mathrm{mg} / \mathrm{mL}$ prepared with PBS was added, and then the mixture was incubated at $37^{\circ} \mathrm{C}$ for $120 \mathrm{~min}$. Trolox diluted in PBS was used as antioxidant standard $(10-80 \mu \mathrm{M})$. The fluorescent values were recorded every minute over the incubation period, at $458 \mathrm{~nm}$ and $520 \mathrm{~nm}$ using a Synergy H1 ${ }^{\mathrm{TM}}$ microplate reader (BioTek Instruments, Inc., Winooski, VT, USA, EUA) and the experiment was carried out in triplicate.

The area under the curve (AUC) over the incubation period values were calculated by subtracting the AUC of the negative control or blank from all the results. Regression equations between net AUC and antioxidant concentration were calculated. The antioxidant capacity (ORAC value) was expressed in $\mu$ moles of Trolox equivalents (TE) per grams of sample and the following equation was used [74]:

ORAC VALUE $($ umoles TE/g $)=($ umoles TE/L $) \times D F \times($ L solvent/g sample $)$ 
where ORAC values ( $\mu$ moles TE/L) correspond to the $\mathrm{x}$ value obtained from Trolox linear regression $(\mathrm{y}=\mathrm{mx}+\mathrm{b})$ by replacing $\mathrm{y}$ from the AUC sample values, $D F$ represents dilution factor, and L solvent/g sample is the volume of prepared mother solution/mass of sample mother solution.

\subsection{Differential Scanning Calorimetry (DSC)}

The thermal characteristics of the samples (melting, crystallization, and decomposition temperatures) were measured on a 204 F1 Phoenix DSC (Netzsch, Selb, Germany). The samples were weighed $(4 \mathrm{mg})$ in a pierced lid aluminium pan and analyzed under a $\mathrm{N}_{2}$ flow of $40 \mathrm{~mL} / \mathrm{min}$, using the temperature program as follows: First a heating step from 20 to $100{ }^{\circ} \mathrm{C}$ to eliminate the sample thermal history [45]; then, a cooling step to $-50{ }^{\circ} \mathrm{C}$; followed by a second heating step from 50 to $500{ }^{\circ} \mathrm{C}$. The heating and cooling steps were both performed at a constant rate of $10{ }^{\circ} \mathrm{C} / \mathrm{min}$ and only the transitions observed during the cooling and the second heating steps were considered.

\subsection{Statistics}

The results are reported as mean values \pm standard deviation. Data were first analyzed for normality distribution (i.e., Shapiro-Wilk test). A Levene's test was applied to verify the homogeneity of the variances. Afterwards, a one-way ANOVA test was applied with Tukey post hoc test to determine differences within groups. For a two-group comparison, Student's t-test was assayed. The level of significance was set, in general, at 0.05. Analyses of the chromatographic data were performed with the aid of the Jamovi software (v 1.6.3.0, The jamovi project (2020)), retrieved from https:/ / www.jamovi.org; accessed on 7 December 2020).

Analyses of data from cytotoxicity and immune response assays were performed with the aid of Graph Pad Prims 6.0 (Graphpad ${ }^{\circledR}$ software). For PCA and Heatmaps, the web-based tool suite Metaboanalyst (v 5.0) was used (https:/ / www.metaboanalyst.ca/; accessed on 13 January 2021).

\section{Conclusions}

The reported results in this research work showed, for the first time, that biowaste from industrial fermentation activity can be a valuable source of bioactive lipids. Thus, it was possible to recover, through molecular distillation, a fraction enriched in novel triterpenes (acting as coadjuvants) and bioactive lipids as 1-octacosanol and phytosterols. The assayed stability tests highlighted that such mixtures of lipids can undergo oxidation since concentrations of phytosterols decreased during the assayed stability time and 1octacosanol totally disappeared. Further applications need to devise a procedure to prevent this degradation, namely by avoiding any contact with oxygen. This should be the next step before future studies exploring health applications for these extracts.

However, those changes did not result in in vitro toxicity for macrophages. Moreover, the obtained extracts showed anti-inflammatory capacity as they were able to decrease TNF- $\alpha$ and IL- 6 in the presence of LPS, which could be related to the presence of phytosterol and triterpene molecules.

Supplementary Materials: The following are available online at https: / / www.mdpi.com/article / 10.3390/ph14060583/s1, Supplementary Methods and Materials (Polymer isolation from sample, Shotgun QTOF, LC-MS analyses), Figure S1. Chromatographic overlay of the triterpene eluting region of the assayed samples, Figure S2. Mass spectra (GC-MS) of triterpene I in the assayed samples, Figure S3. Mass spectra (GC-MS) of triterpene III in the assayed samples, Figure S4. Mass spectra (GC-MS) of triterpene IV in the assayed samples, Figure S5. Mass spectra (GC-MS) of triterpene VIII in the assayed samples, Figure S6. Mass spectra (GC-MS) of squalene (Standard from Sigma), Figure S7. Direct infusion on QTOF of FDR sample treated with methanol showed a gaussian distribution of ions, Figure S8. Mass spectra (LC-QTOF) at start (A), middle (B) and end (C) of eluting peak of methanol-treated FDR sample, Figure S9. PCA of data obtained from GC-MS (A) and HPLC-ELSD (B), Figure S10. Heatmap of GC-MS data from the assayed samples, Figure S11. Heatmap of HPLC-ELSD 
data from the assayed samples, Table S1. Mobile phase gradient (\%), Table S2. FTIR frequencies interpretation table, Table S3. Quantification of IL-1 $\beta$, IL-6, IL-8 and TNF- $\alpha$ levels in macrophages without and with inflammatory stimulus (LPS), Supplemetary References.

Author Contributions: Conceptualization, L.M.R.-A.; methodology, S.S.M.P.V., L.L.P., J.A.-S., J.C.F. and L.M.R.-A.; formal analysis, J.A.-S. and L.M.R.-A.; investigation, F.S.T., S.S.M.P.V., L.L.P., P.T.C., D.T.-V. and J.A.-S.; data curation, S.S.M.P.V., L.L.P., J.A.-S. and L.M.R.-A.; writing-original draft preparation, F.S.T., S.S.M.P.V., L.L.P., P.T.C., J.A.-S. and L.M.R.-A.; writing-review and editing, F.S.T., S.S.M.P.V., L.L.P., P.T.C., D.T.-V., J.A.-S., M.E.P., J.C.F. and L.M.R.-A.; visualization, F.S.T., S.S.M.P.V., L.L.P., P.T.C., D.T.-V., J.A.-S. and L.M.R.-A.; supervision, S.S.M.P.V., L.L.P., J.A.-S., J.C.F. and L.M.R.-A.; project administration, L.M.R.-A.; funding acquisition, M.E.P. and J.C.F. All authors have read and agreed to the published version of the manuscript.

Funding: This work was supported by Amyris Bio Products Portugal Unipessoal Lda and Escola Superior de Biotecnologia-Universidade Católica Portuguesa through the Alchemy project, Capturing High Value from Industrial Fermentation Bioproducts (POCI-01-0247-FEDER-027578). Authors would also like to thank the scientific collaboration under the FCT project UID/Multi/50016/2019.

Institutional Review Board Statement: Not applicable.

Informed Consent Statement: Not applicable.

Data Availability Statement: Data is contained within the article or Supplementary Materials.

Acknowledgments: The authors also express a special thanks to Alessandro Montpetit (Amyris Inc.) for collecting the fractions.

Conflicts of Interest: The authors declare no conflict of interest.

\begin{abstract}
Abbreviations
Phospholipids (PLS), triglycerides (TG), diglycerides (DG), free fatty acids (FFA), fatty alcohols (FOH), 1-octacosanol (FOH 28:0), dichloromethane (DCM), ethanol (EtOH), acetone (AcO) or ethyl acetate (EtAc), triethylamine (TEA), N, O-Bis(trimethylsilyl) trifluoroacetamide with $1 \%$ trimethylchlorosilane (BSTFA), trimethylsilyl derivatives (TMS), fatty aldehydes (FAL), sterols (ST), phosphatidylethanolamine (PE), phosphatidylcholine (PC), phosphatidylinositol (PI), tritriacontane (C33:0), campesterol (ST C28:1;O), stigmasterol (ST 29:2;O), $\beta$-sitosterol (ST 29:1;O), and stigmast-4en-3-one (ST29:2;O2).
\end{abstract}

\title{
References
}

1. United Nations. World Population Prospects 2019; United Nations: New York, NY, USA, 2019; ISBN 9789211483161.

2. Bell, J.; Paula, L.; Dodd, T.; Németh, S.; Nanou, C.; Mega, V.; Campos, P. EU ambition to build the world's leading bioeconomyUncertain times demand innovative and sustainable solutions. N. Biotechnol. 2018, 40, 25-30. [CrossRef]

3. Pimentel, D.; Burgess, M. World human population problems. In Encyclopedia of the Anthropocene; Elsevier: Amsterdam, The Netherlands, 2017; Volume 1-5, pp. 313-317. ISBN 9780128096659.

4. Willett, W.; Rockström, J.; Loken, B.; Springmann, M.; Lang, T.; Vermeulen, S.; Garnett, T.; Tilman, D.; DeClerck, F.; Wood, A.; et al. Food in the Anthropocene: The EAT-Lancet Commission on healthy diets from sustainable food systems. Lancet 2019, 393, 447-492. [CrossRef]

5. Geissdoerfer, M.; Savaget, P.; Bocken, N.M.P.; Hultink, E.J. The Circular Economy-A new sustainability paradigm? J. Clean. Prod. 2017, 143, 757-768. [CrossRef]

6. Hanson, R. The Great Filter. Available online: http://mason.gmu.edu/ \{\}rhanson/greatfilter.html (accessed on $21 \mathrm{March} 2021)$.

7. D'Amato, D.; Droste, N.; Allen, B.; Kettunen, M.; Lähtinen, K.; Korhonen, J.; Leskinen, P.; Matthies, B.D.; Toppinen, A. Green, circular, bio economy: A comparative analysis of sustainability avenues. J. Clean. Prod. 2017, 168, 716-734. [CrossRef]

8. Lee, J.K.; Patel, S.K.S.; Sung, B.H.; Kalia, V.C. Biomolecules from municipal and food industry wastes: An overview. Bioresour. Technol. 2020, 298, 122346. [CrossRef]

9. Mello, B.L.B.; Fernandes, A.M.; de Oliveira, T.S.; Leonel, F.P.; Glória, L.S.; Silva, R.S.T. Feed intake, digestibility, and energy contents in growing bull fed pineapple crop waste silage in different planes of nutrition. Trop. Anim. Health Prod. 2021, 53, 188. [CrossRef]

10. Klunklin, W.; Jantanasakulwong, K.; Phimolsiripol, Y.; Leksawasdi, N.; Seesuriyachan, P.; Chaiyaso, T.; Insomphun, C.; Phongthai, S.; Jantrawut, P.; Sommano, S.R.; et al. Synthesis, characterization, and application of carboxymethyl cellulose from asparagus stalk end. Polymers 2021, 13, 81. [CrossRef] 
11. Piccirillo, C.; Rocha, C.; Tobaldi, D.M.; Pullar, R.C.; Labrincha, J.A.; Ferreira, M.O.; Castro, P.M.L.; Pintado, M.M.E. A hydroxyapatite-Fe2O3 based material of natural origin as an active sunscreen filter. J. Mater. Chem. B 2014, 2, 5999-6009. [CrossRef] [PubMed]

12. OECD-FAO Agricultural Outlook 2015-2024; OECD: Paris, France, 2015.

13. Roukas, T.; Kotzekidou, P. Rotary biofilm reactor: A new tool for long-term bioethanol production from non-sterilized beet molasses by Saccharomyces cerevisiae in repeated-batch fermentation. J. Clean. Prod. 2020, 257, 120519. [CrossRef]

14. Bušić, A.; Mardetko, N.; Kundas, S.; Morzak, G.; Belskaya, H.; Šantek, M.I.; Komes, D.; Novak, S.; Šantek, B. Bioethanol production from renewable raw materials and its separation and purification: A review. Food Technol. Biotechnol. 2018, 56, 289-311. [CrossRef] [PubMed]

15. Zabed, H.; Sahu, J.N.; Suely, A.; Boyce, A.N.; Faruq, G. Bioethanol production from renewable sources: Current perspectives and technological progress. Renew. Sustain. Energy Rev. 2017, 71, 475-501. [CrossRef]

16. Jambo, S.A.; Abdulla, R.; Mohd Azhar, S.H.; Marbawi, H.; Gansau, J.A.; Ravindra, P. A review on third generation bioethanol feedstock. Renew. Sustain. Energy Rev. 2016, 65, 756-769. [CrossRef]

17. FAOSTAT. FAOSTAT: Statistical Database. Available online: http://www.fao.org/faostat/en/\#home (accessed on 1 September 2020).

18. Fadhil, A.B.; Al-Tikrity, E.T.B.; Albadree, M.A. Biodiesel production from mixed non-edible oils, castor seed oil and waste fish oil. Fuel 2017, 210, 721-728. [CrossRef]

19. Nautiyal, P.; Subramanian, K.A.; Dastidar, M.G. Experimental investigation on performance and emission characteristics of a compression ignition engine fueled with biodiesel from waste tallow. Clean Technol. Environ. Policy 2017, 19, 1667-1677. [CrossRef]

20. Xu, P.; Vansiri, A.; Bhan, N.; Koffas, M.A.G. EPathBrick: A synthetic biology platform for engineering metabolic pathways in E. coli. ACS Synth. Biol. 2012, 1, 256-266. [CrossRef]

21. Zhang, J.; Chen, Y.; Fu, L.; Guo, E.; Wang, B.; Dai, L.; Si, T. Accelerating strain engineering in biofuel research via build and test automation of synthetic biology. Curr. Opin. Biotechnol. 2021, 67, 88-98. [CrossRef]

22. Zhang, Y.; Nielsen, J.; Liu, Z. Engineering yeast metabolism for production of terpenoids for use as perfume ingredients, pharmaceuticals and biofuels. FEMS Yeast Res. 2017, 17, 1-11. [CrossRef]

23. Paddon, C.J.; Westfall, P.J.; Pitera, D.J.; Benjamin, K.; Fisher, K.; McPhee, D.; Leavell, M.D.; Tai, A.; Main, A.; Eng, D.; et al. High-level semi-synthetic production of the potent antimalarial artemisinin. Nature 2013, 496, 528-532. [CrossRef]

24. Meadows, A.L.; Hawkins, K.M.; Tsegaye, Y.; Antipov, E.; Kim, Y.; Raetz, L.; Dahl, R.H.; Tai, A.; Mahatdejkul-Meadows, T.; Xu, L.; et al. Rewriting yeast central carbon metabolism for industrial isoprenoid production. Nature 2016, 537, 694-697. [CrossRef] [PubMed]

25. Ejsing, C.S.; Sampaio, J.L.; Surendranath, V.; Duchoslav, E.; Ekroos, K.; Klemm, R.W.; Simons, K.; Shevchenko, A. Global analysis of the yeast lipidome by quantitative shotgun mass spectrometry. Proc. Natl. Acad. Sci. USA 2009, 106, 2136-2141. [CrossRef] [PubMed]

26. Liu, C.; Zhao, S.; Zhu, C.; Gao, Q.; Bai, J.; Si, J.; Chen, Y. Ergosterol ameliorates renal inflammatory responses in mice model of diabetic nephropathy. Biomed. Pharmacother. 2020, 128, 110252. [CrossRef]

27. Nallathamby, N.; Guan-Serm, L.; Vidyadaran, S.; Malek, S.N.A.; Raman, J.; Sabaratnam, V. Ergosterol of Cordyceps militaris Attenuates LPS Induced Inflammation in BV2 Microglia Cells. Nat. Prod. Commun. 2015, 10. [CrossRef]

28. Asikin, Y.; Takahashi, M.; Hirose, N.; Hou, D.X.; Takara, K.; Wada, K. Wax, policosanol, and long-chain aldehydes of different sugarcane (Saccharum officinarum L.) cultivars. Eur. J. Lipid Sci. Technol. 2012, 114, 583-591. [CrossRef]

29. del Río, J.C.; Marques, G.; Lino, A.G.; Lima, C.F.; Colodette, J.L.; Gutiérrez, A. Lipophilic phytoSSSSSSchemicals from sugarcane bagasse and straw. Ind. Crops Prod. 2015, 77, 992-1000. [CrossRef]

30. Guo, T.; Lin, Q.; Li, X.; Nie, Y.; Wang, L.; Shi, L.; Xu, W.; Hu, T.; Guo, T.; Luo, F. Octacosanol Attenuates Inflammation in Both RAW264.7 Macrophages and a Mouse Model of Colitis. J. Agric. Food Chem. 2017, 65, 3647-3658. [CrossRef] [PubMed]

31. Pimentel, L.L.; Rodríguez-Alcalá, L.M. Cholesterol, inflammation, and phospholipids: COVID-9 share traits with cardiovascular disease. Biochim. Biophys. Acta Mol. Cell Biol. Lipids 2021, 1866. [CrossRef] [PubMed]

32. Sugawara, T.; Miyazawa, T. Separation and determination of glycolipids from edible plant sources by high-performance liquid chromatography and evaporative light-scattering detection. Lipids 1999, 34, 1231-1237. [CrossRef] [PubMed]

33. Fouquet, T.N.J. The Kendrick analysis for polymer mass spectrometry. J. Mass Spectrom. 2019, 54, 933-947. [CrossRef] [PubMed]

34. Yoo, T.; Henning, S.K. Synthesis and characterization of farnesene-based polymers. Rubber Chem. Technol. 2017, 90, 308-324. [CrossRef]

35. Sahu, P.; Bhowmick, A.K. Redox Emulsion Polymerization of Terpenes: Mapping the Effect of the System, Structure, and Reactivity. Ind. Eng. Chem. Res. 2019, 58, 20946-20960. [CrossRef]

36. Fisher, K.; Woolard, F.X. Farnesene Dimers and/or Farnesane Dimers and Compositions Thereof. U.S. Patent 7,592,295, 22 September 2009.

37. Reddy, L.H.; Couvreur, P. Squalene: A natural triterpene for use in disease management and therapy. Adv. Drug Deliv. Rev. 2009, 61, 1412-1426. [CrossRef] [PubMed]

38. Tegenge, M.A.; Von Tungeln, L.S.; Anderson, S.A.; Mitkus, R.J.; Vanlandingham, M.M.; Forshee, R.A.; Beland, F.A. Comparative pharmacokinetic and biodistribution study of two distinct squalene-containing oil-in-water emulsion adjuvants in H5N1 influenza vaccines. Regul. Toxicol. Pharmacol. 2019, 108, 104436. [CrossRef] 
39. Dormont, F.; Brusini, R.; Cailleau, C.; Reynaud, F.; Reynaud, F.; Peramo, A.; Gendron, A.; Mougin, J.; Gaudin, F.; Gaudin, F.; et al. Squalene-based multidrug nanoparticles for improved mitigation of uncontrolled inflammation in rodents. Sci. Adv. 2020, 6, eaaz5466. [CrossRef] [PubMed]

40. Feng, J.; Lepetre-Mouelhi, S.; Gautier, A.; Mura, S.; Cailleau, C.; Coudore, F.; Hamon, M.; Couvreur, P. A new painkiller nanomedicine to bypass the blood-brain barrier and the use of morphine. Sci. Adv. 2019, 5, eaau5148. [CrossRef]

41. Sharma, R.; Matsuzaka, T.; Kaushik, M.K.; Sugasawa, T. Octacosanol and policosanol prevent high-fat diet-induced obesity and metabolic disorders by activating brown adipose tissue and improving liver metabolism. Sci. Rep. 2019, 9, 5169. [CrossRef] [PubMed]

42. Lee, S.; Scott, S.D.; Pekas, E.J.; Lee, J.; Park, S. Improvement of Lipids and Reduction of Oxidative Stress with Octacosanol after Taekwondo Training. Int. J. Sports Physiol. Perform. 2019, 14, 1297-1303. [CrossRef]

43. Kaushik, M.K.; Aritake, K.; Takeuchi, A.; Yanagisawa, M.; Urade, Y. Octacosanol restores stress-affected sleep in mice by alleviating stress. Sci. Rep. 2017, 7, 8892. [CrossRef]

44. European Comission COMMISSION REGULATION (EU) No 432/2012 of 16 May 2012 establishing a list of permitted health claims made on foods, other than those referring to the reduction of disease risk and to children's development and health. Off. J. Eur. Union 2012, L136, 1-40. Available online: http:/ / eur-lex.europa.eu/pri/en/oj/dat/2003/1_285/1_28520031101en00330037. pdf (accessed on 1 January 2021).

45. Attard, T.M.; McElroy, C.R.; Rezende, C.A.; Polikarpov, I.; Clark, J.H.; Hunt, A.J. Sugarcane waste as a valuable source of lipophilic molecules. Ind. Crops Prod. 2015, 76, 95-103. [CrossRef]

46. Ishaka, A.; Imam, M.U.; Mahamud, R.; Zuki, A.B.Z.; Maznah, I. Characterization of rice bran wax policosanol and its nanoemulsion formulation. Int. J. Nanomedicine 2014, 9, 2261-2269. [CrossRef]

47. Canizares, D.; Angers, P.; Ratti, C. Selective wax recovery from flax and wheat straw. Ind. Crops Prod. 2019, 141, 111700. [CrossRef]

48. Rahmania, H.; Kato, S.; Sawada, K.; Hayashi, C.; Hashimoto, H.; Nakajima, S.; Otoki, Y.; Ito, J.; Nakagawa, K. Revealing the thermal oxidation stability and its mechanism of rice bran oil. Sci. Rep. 2020, 10, 14091. [CrossRef] [PubMed]

49. Feng, S.; Luo, Z.; Zeng, F.; Liu, S.; Khan, Z.U. Effect of water, metallic ions, fatty acid and temperature on oxidative stability of 1-octacosanol from sugarcane rind. Food Chem. 2015, 182, 171-177. [CrossRef] [PubMed]

50. Ishida, T.; Ogihara, Y.; Ohashi, H.; Akita, T.; Honma, T.; Oji, H.; Haruta, M. Base-free direct oxidation of 1-octanol to octanoic acid and its octyl ester over supported gold catalysts. ChemSusChem 2012, 5, 2243-2248. [CrossRef] [PubMed]

51. Corberán, V.C.; Gómez-Avilés, A.; Martínez-González, S.; Ivanova, S.; Domínguez, M.I.; González-Pérez, M.E. Heterogeneous selective oxidation of fatty alcohols: Oxidation of 1-tetradecanol as a model substrate. Catal. Today 2014, 238, 49-53. [CrossRef]

52. Ekinci, N.; Şeker, M.; Aydin, F.; Gündoğdu, M.A. Possible chemical mechanism and determination of inhibitory effects of 1-MCP on superficial scald of the Granny Smith apple variety. Turk. J. Agric. For. 2016, 40, 38-44. [CrossRef]

53. Gachumi, G.; Poudel, A.; Wasan, K.M.; El-Aneed, A. Analytical strategies to analyze the oxidation products of phytosterols, and formulation-based approaches to reduce their generation. Pharmaceutics 2021, 13, 268. [CrossRef]

54. Lengyel, J.; Rimarčík, J.; Vagánek, A.; Fedor, J.; Lukeš, V.; Klein, E. Oxidation of sterols: Energetics of C-H and O-H bond cleavage. Food Chem. 2012, 133, 1435-1440. [CrossRef]

55. Choe, E.; Min, D.B. Mechanisms and Factors for Edible Oil Oxidation. Compr. Rev. Food Sci. Food Saf. 2006, 5, 169-186. [CrossRef]

56. Khor, Y.P.; Shin Hew, K.; Abas, F.; Lai, O.M.; Cheong, L.Z.; Nehdi, I.A.; Sbihi, H.M.; Gewik, M.M.; Tan, C.P. Oxidation and Polymerization of Triacylglycerols: In-Depth Investigations towards the Impact of Heating Profiles. Foods 2019, 8, 475. [CrossRef]

57. Rodríguez-Alcalá, L.M.; García-Martínez, M.C.; Cachón, F.; Marmesat, S.; Alonso, L.; Márquez-Ruiz, G.; Fontecha, J. Changes in the lipid composition of powdered infant formulas during long-term storage. J. Agric. Food Chem. 2007, 55, 6533-6538. [CrossRef]

58. del Carmen García-Martínez, M.; Rodríguez-Alcalá, L.M.; Marmesat, S.; Alonso, L.; Fontecha, J.; Márquez-Ruiz, G. Lipid stability in powdered infant formula stored at ambient temperatures. Int. J. Food Sci. Technol. 2010, 45, 2337-2344. [CrossRef]

59. de Almeida, D.T.; Viana, T.V.; Costa, M.M.; Silva, C.D.S.; Feitosa, S. Effects of different storage conditions on the oxidative stability of crude and refined palm oil, olein and stearin (Elaeis guineensis). Food Sci. Technol. 2019, 39, 211-217. [CrossRef]

60. Toci, A.T.; Neto, V.J.M.F.; Torres, A.G.; Farah, A. Changes in triacylglycerols and free fatty acids composition during storage of roasted coffee. LWT-Food Sci. Technol. 2013, 50, 581-590. [CrossRef]

61. Kim, S.M.; Chung, H.J.; Lim, S.T. Effect of various heat treatments on rancidity and some bioactive compounds of rice bran. J. Cereal Sci. 2014, 60, 243-248. [CrossRef]

62. Aldini, R.; Micucci, M.; Cevenini, M.; Fato, R.; Bergamini, C.; Nanni, C.; Cont, M.; Camborata, C.; Spinozzi, S.; Montagnani, M.; et al. Antiinflammatory Effect of Phytosterols in Experimental Murine Colitis Model: Prevention, Induction, Remission Study. PLoS ONE 2014, 9, e108112. [CrossRef] [PubMed]

63. Yuan, L.; Zhang, F.; Shen, M.; Jia, S.; Xie, J. Phytosterols suppress phagocytosis and inhibit inflammatory mediators via ERK pathway on LPS-triggered inflammatory responses in RAW264.7 macrophages and the correlation with their structure. Foods 2019, 8, 582. [CrossRef]

64. CPMP/ICH. ICH Topic Q1 A Stability Testing Guidelines: Stability Testing of New Drug Substances and Products. Int. Conf. Harmon. 2003, 4, 1-14.

65. Greenspan, L. Humidity fixed points of binary saturated aqueous solutions. J. Res. Natl. Bur. Stand. Sect. A Phys. Chem 1977, 81A, 89-96. [CrossRef] 
66. Abreu, S.; Solgadi, A.; Chaminade, P. Optimization of normal phase chromatographic conditions for lipid analysis and comparison of associated detection techniques. J. Chromatogr. A 2017, 1514, 54-71. [CrossRef] [PubMed]

67. Homan, R.; Anderson, M.K. Rapid separation and quantitation of combined neutral and polar lipid classes by high-performance liquid chromatography and evaporative light- scattering mass detection. J. Chromatogr. B Biomed. Appl. 1998, 708, 21-26. [CrossRef]

68. George, S. Infrared and Raman Characteristic Group Frequencies Contents, 3rd ed.; John Wiley \& Sons, Inc.: London, UK, 2001; ISBN 0471852988.

69. Bobo-García, G.; Davidov-Pardo, G.; Arroqui, C.; Vírseda, P.; Marín-Arroyo, M.R.; Navarro, M. Intra-laboratory validation of microplate methods for total phenolic content and antioxidant activity on polyphenolic extracts, and comparison with conventional spectrophotometric methods. J. Sci. Food Agric. 2015, 95, 204-209. [CrossRef]

70. Oliveira, S. Evaluation of antiradical assays used in determining the antioxidant capacity of pure compounds and plant extracts. Quim. Nov. 2014, 37, 497-503. [CrossRef]

71. Sanchez-Moreno, C. Review: Methods used to evaluate the free radical scavenging activity in foods and biological systems. Food Sci. Technol. Int. 2002, 8, 121-137. [CrossRef]

72. Benteldjoune, M.; Boudiar, T.; Bakhouche, A.; Contreras, M.; Lozano-sánchez, J.; Bensouici, C.; Kabouche, Z.; Segura-carretero, A.; Contreras, M.; Lozano-sánchez, J.; et al. Antioxidant activity and characterization of flavonoids and phenolic acids of Ammoides atlantica by RP-UHPLC-ESI-QTOF-MS. Nat. Prod. Res. 2019, 1-5. [CrossRef]

73. Dávalos, A.; Gómez-Cordovés, C.; Bartolomé, B. Extending Applicability of the Oxygen Radical Absorbance Capacity (ORAC-Fluorescein) Assay. J. Agric. Food Chem. 2004, 52, 48-54. [CrossRef] [PubMed]

74. Yu, L. (Ed.) Wheat Antioxidants; John Wiley \& Sons, Inc.: Hoboken, NJ, USA, 2007; ISBN 9780470228333. 